IZA DP No. 8148

Structural Change and Innovation as Exit Strategies from the Middle Income Trap

Marco Vivarelli

April 2014 


\title{
Structural Change and Innovation as Exit Strategies from the Middle Income Trap
}

\author{
Marco Vivarelli \\ Università Cattolica del Sacro Cuore-Piacenza \\ and IZA
}

Discussion Paper No. 8148

April 2014

IZA

P.O. Box 7240

53072 Bonn

Germany

Phone: +49-228-3894-0

Fax: +49-228-3894-180

E-mail: iza@iza.org

\begin{abstract}
Any opinions expressed here are those of the author(s) and not those of IZA. Research published in this series may include views on policy, but the institute itself takes no institutional policy positions. The IZA research network is committed to the IZA Guiding Principles of Research Integrity.

The Institute for the Study of Labor (IZA) in Bonn is a local and virtual international research center and a place of communication between science, politics and business. IZA is an independent nonprofit organization supported by Deutsche Post Foundation. The center is associated with the University of Bonn and offers a stimulating research environment through its international network, workshops and conferences, data service, project support, research visits and doctoral program. IZA engages in (i) original and internationally competitive research in all fields of labor economics, (ii) development of policy concepts, and (iii) dissemination of research results and concepts to the interested public.
\end{abstract}

IZA Discussion Papers often represent preliminary work and are circulated to encourage discussion. Citation of such a paper should account for its provisional character. A revised version may be available directly from the author. 


\section{ABSTRACT \\ Structural Change and Innovation as Exit Strategies from the Middle Income Trap*}

This paper is intended to provide an updated discussion on a series of issues that the relevant literature suggests to be crucial in dealing with the challenges a middle income country may encounter in its attempts to further catch-up a higher income status. In particular, the conventional economic wisdom - ranging from the Lewis-Kuznets model to the endogenous growth approach - will be contrasted with the Schumpeterian and evolutionary views pointing to the role of capabilities and knowledge, considered as key inputs to foster economic growth. Then, attention will be turned to structural change and innovation, trying to map - using the taxonomies put forward by the innovation literature - the concrete ways through which a middle income country can engage a technological catching-up, having in mind that developing countries are deeply involved into globalized markets where domestic innovation has to be complemented by the role played by international technological transfer. Among the ways how a middle income country can foster domestic innovation and structural change in terms of sectoral diversification and product differentiation, a recent stream of literature underscores the potentials of local innovative entrepreneurship, that will also be discussed bridging entrepreneurial studies with the development literature. Finally, the possible consequences of catching-up in terms of jobs and skills will be discussed.

JEL Classification: $\quad 014,033$

Keywords: catching-up, structural change, globalization, capabilities, innovation, entrepreneurship

Corresponding author:

Marco Vivarelli

Facoltà di Economia e Giurisprudenza

Università Cattolica del Sacro Cuore

Via Emilia Parmense 84

I-29122 Piacenza

Italy

E-mail: marco.vivarelli@unicatt.it

\footnotetext{
* This study has been developed as a background paper for the International Labour Office (ILOGeneva)
} 


\section{Introduction}

This survey is intended to provide an updated discussion on some key issues that the relevant literature suggests to be crucial in dealing with the challenges a middle income country may encounter in its attempts to further catch-up a higher income status.

While the current state-of-the-art will be covered, a particular attention will be devoted to those interpretative frameworks that underscore the key role of capabilities, structural change and technological progress in fostering a development country's (DC henceforth) capacity to climb up the income ladder.

In particular, the conventional economic wisdom - ranging from the Lewis-Kuznets model to the endogenous growth approach- will be contrasted with the Schumpeterian and evolutionary views pointing to the role of capabilities and knowledge, considered as key inputs to foster economic growth. In this framework, the attention will be focused on capabilities building, structural change intended as both domestic sectoral specialization and consequent export content - and innovation.

Far from considering human capital, structural change and innovation as exogenous variables - as mainstream economics do - this study will try to endogenize these drivers of growth and map their nature, their determinants (including policy intervention) and their consequences in terms of economic catch-up, job creation and skills.

In more detail, the next section will be devoted to briefly summarize the recent literature on the so called "middle income trap" (MIT henceforth), also giving account of the various possible solutions put forward by previous studies. Among the proposed escapes from the MIT, our focus will be centered on long-term structural strategies, while short-term and infrastructural policies will just briefly recalled in the conclusive section.

The long-term strategies that can be considered as permanent solutions to the MIT are discuused in Sections 3 and 4. In particular, Section 3 will be devoted to discuss what can be proposed as a condition-sine-qua-non for triggering structural and technological change, that is the availability of competences and capabilities able to maximize both the endogenous supply of knowledge by a middle income DC and its "absorptive capacity" of knowledge coming from more advanced economies. Section 4 will focus on structural change and innovation, trying to map - using the taxonomies put forward by the innovation literature - the concrete ways through which a middle income country can engage a technological catching-up.

However, knowledge, innovation and structural change do not come out of the blue (as mainstream economics tends to think), but must be implemented in a given economic system through concrete actions and specific channels. Section 5 will be devoted to discuss these different channels, having in mind that middle income countries are deeply involved into globalized markets where domestic innovation has to be complemented by the role - sometimes much more important for a DC played by international technological transfer.

Among the ways how a middle income country can foster domestic innovation and structural change in terms of sectoral diversification and product differentiation, a recent stream of literature underscores the potentials of local innovative entrepreneurship; Section 6 will survey the literature 
bridging entrepreneurial studies with the development literature in the context set up by the previous sections.

While increased capabilities, structural change, innovation and entrepreneurship appear the most effective ways outs from the MIT, their possible impacts in terms of job creation and skillupgrading cannot be taken as granted, but may be rather controversial. Section 7 will be devoted to study the effects on employment and skills of what analyzed in the previous sections.

Finally, Section 8 will summarize the main findings of this study and will discuss some policy implications.

\section{The middle income trap: evidences and possible ways out}

During the last decade an important debate has arisen around the empirical observation that the majority of countries that managed to cross the middle-income threshold in the second half of the XX century have not yet been able to graduate into the high-income-countries club. This has been defined by Gill and Kharas (2007) as the "middle income trap".

The World Bank (2012) concludes that out of 101 middle income countries in 1960, only 13 graduated to the high-income category by 2008. Most of Latin America and all the MENA countries are examples of countries currently trapped in the MIT. In particular, several Latin American economies appear to be trapped over a long-term perspective, having failed to achieve high income levels despite attaining a middle income status several decades ago. By contrast, several Asian economies (Japan in primis, the four Asian tigers later) are considered a kind of benchmark, since they have continued to grow, thereby achieving per capita income levels comparable to OECD countries.

In a nutshell, the process of development driving a low-income country into the middle-income group can still be explained within a Lewis-Kuznets framework: during their initial stage of development, poorest countries can rely on the structural reallocation of labor from the low productivity sectors (mainly agriculture and traditional/personal services in rural areas) to highproductivity manufacturing, mainly located in the urban areas (see Kuznets, 1955; Lewis, 1955; Rostow, 1959; Kuznets, 1963; Kaldor (1967); for a recent model revisiting this approach, see Grimalda and Vivarelli, 2010).

This scenario substantially changes when countries that have revealed high growth potentialities in exiting from a low-income status, enter in a later stage of development. Indeed, when these countries reach the middle-income level, the pool of unemployed and underemployed rural workers drain out, wages start to rise, benefits from imitation and importing foreign mature technologies decrease in importance and capital accumulation starts to show decreasing returns and difficulties to grasp further scale economies (see Perez-Sebastian, 2007; Agenor and Canuto, 2012; Agenor et al. 2012). 
Empirically, Spence (2011) singled out the range between $\$ 5,000$ and $\$ 10,000$ per capita income as the stage of development where the transition to higher income levels becomes very problematic. In a more recent study, Eichengreen et al. (2013) - searching for structural breaks applying the Chow test to a sample of formerly fast-growing middle income countries - showed that the likelihood of sudden slowdowns is bi-modal having its peaks in the range of 10,000-11,000 constant US dollars at 2005 PPP and in the higher interval 15,000-16,000. This new evidence imply that a large group of middle income countries is at risk of being framed in a MIT.

It is important to recall that the literature points out that the growth slowdowns which signal the entering into the MIT are essentially productivity slowdowns rather than simply the consequence of decreasing returns in physical capital accumulation. In more detail, Eichengreen et al. (2012) estimate that $85 \%$ of growth slowdown is due to total factor productivity (TFP), while only $15 \%$ to capital accumulation. Daude an Fernandez-Arias (2010) got very similar results showing that TFP plays a key role in explaining the per capita income gap of Latin American and Caribbean countries, while differences in factor accumulation are shown to be substantially less important. These evidences point to the key roles of human capital, structural change and innovation as the main drivers of total factor productivity growth and so as possible solutions to the MIT.

Indeed, the current literature has focused on the changing structure of the economy (diversification from low productivity sectors into high-productivity ones) and on the types of product exported as the most important drivers able to generate a possible way out from the MIT. Indeed, Hidalgo et al. (2007) and Hidalgo and Hausmann (2009) describe economic development as a process based on building capabilities and learning capacities that allow a country to produce and export more complex and sophisticated goods throughout a continuous process of diversification (that is entering into new sectors), product differentiation (that is to increase the variety and the characteristics of goods) and product up-grading (that is to improve the quality of the existing goods).

This framework have been applied to the MIT problem and several studies actually confirmed that these strategies can play a key role in escaping from the MIT. For instance, Felipe et al. (2012) compare the exports of countries in the MIT with those that managed to escape from it, using eight dimensions capturing country's diversification, sophistication of the export basket, potential for a country structural change and so on so forth (most of these indexes make use of the Balassa index of revealed comparative advantages, see Balassa 1965 and 1977; for a recent discussion, see Laursen, 2014). The authors found that the product profiles of the two groups are substantially different with countries escaped from the MIT (for instance, South Korea is studied in details) having more diversified, sophisticated and non-standard export baskets at the time they were about to make the jump. By the same token, Jankowska et al. (2012) applied a "product space” approach to a sample of Latin American and Asian countries, estimating the impact of both diversification into new sectors (extensive, widening strategy) and of increasing a country's export share in current highly sophisticated sectors (intensive, deepening strategy). The authors found that, although all countries managed to increase the number of industries in which they reveal a comparative advantage (measured through the Balassa index), significant differences in the evolution of the countries' product spaces emerge with country like Korea standing out and others like Brazil and Mexico lagging behind. Finally, Eichengreen et al., (2013) found that high-tech exports (both manufacturing goods and services) significantly reduce the likelihood of growth slowdowns (together with high quality human capital)

On the whole, the (mainly empirical) literature on the MIT clearly suggests the roles of capabilities, structural change and technological progress as the key factors able to better positioning a middle 
income country in front of the challenges posed by the risk to enter into a MIT. Nevertheless, this literature fails to go beyond these empirical suggestions and lacks a proper theoretical framework.

The aim of the following sections is try to open the "black boxes" and - differently from previous literature and from most of mainstream approaches - to go inside the concepts of capabilities, structural change and innovation. Indeed, albeit recognizing their roles, the mainstream literature consider these key variables as "exogenous" (something like "manna from heaven"), invoking them but avoiding to explicitly discuss the ways how capability building, structural change and innovation (and their interactions shaping a proper co-evolving "match") can actually take place in a developing country.

\section{$\underline{\text { 3. Competences and capabilities as core pre-requisites }}$}

As discussed in the previous section, the MIT is not an empirical/unavoidable phenomenon, but something strictly connected with a productivity gap and so, in turn, to technological and structural change. Indeed, even mainstream macroeconomists have recognized the crucial role of innovation. In more details, endogenous growth models have singled out the accumulation of R\&D as one of the main sources of long-term economic growth (see Mankiw et al., 1992; Romer, 1994; Lucas, 2002). In this respect, several studies state that R\&D expenditures represent the main engine of technological progress and economic growth (see Nelson and Winter, 1982; Mansfield, 1988; Aghion and Howitt, 1998).

Nevertheless, mainstream economics looks at innovation as a kind of externality which, basically through R\&D spillovers, can positively affect productivity and eventually economic growth. In contrast, in this study, we will put forward concepts and taxonomies able to look at technology as a concrete phenomenon (see Section 4) that can be shaped by investment decisions (both private and public) and by deliberate public policies, with particular reference to industrial and innovation policies (see Section 8).

However, structural and technological change need a proper "terrain" to develop their own potentialities and ultimately foster productivity growth. To prepare this terrain is the very first challenge a middle income DC has to face in order to deal with the MIT.

Indeed, in this section, attention will be focused on the concept of "capability" as a key preliminary factor to explain why a middle income country is able or not to engage into a successful catching-up (see Fagerberg, 1994; Fagerberg and Godinho, 2005). In fact, R\&D and innovation are the main drivers of productivity and economic growth (see above), one can wonder whether different countries have the same possibilities to domestically produce new knowledge and to absorb the external knowledge, available at the international level. The answer is that this is not the case: indeed, countries have different degrees of capabilities in developing new knowledge and even in take advantage from using the same available technology. The reason is that country-specific structural conditions and "social capabilities" may cause 'incongruences' with respect to a certain basic knowledge and/or applied technology (see Abramovitz, 1986 and 1992): given the same available technologies, only those countries endowed with the adequate social capabilities can 
properly master the new technological opportunities, exploit them in a competent way and ultimately successfully engage a catching-up pattern of growth (see Sutton, 2012).

Moreover, capabilities and cumulated former knowledge are essential in fostering the so-called 'absorptive capacity', that is the ability to exploit further external technological opportunities (see Mowery, 1983; Pavitt, 1984; Cohen and Levinthal, 1989 and 1990; Rosenberg, 1990; Rosenberg, 1994) ${ }^{1}$.

It is important to note that capabilities are crucial not only on the technological frontier (that is to cope with the challenges common to the advanced countries), but as well as in the catching-up (that is the challenge common to DCs). In this framework, capabilities can be considered pre-requisites to allow a middle income country to avoid the MIT and to enter a successful pattern of growth. Indeed, as it will be extensively discussed in Section 5, middle income countries rely less on domestic innovation rather than on the absorption of knowledge developed elsewhere (typically in richer countries and in multinational firms located within the country). If such is the case, the presence of strong domestic capabilities becomes a key factor for a long-term strategy addressed to overcome the MIT (see Lall 1992 and 2004).

Once clarified the key role of domestic capabilities in supporting an exit strategy from the MIT, the rest of this section can be devoted to provide a more articulated discussion of what is meant by "capabilities”.

As a matter of fact, since Nelson and Winter's seminal book (1982), contributions in the area of capabilities have proliferated in and around resource-based views, evolutionary economics, the economics and history of technical change, strategic management and, more recently, evolutionary economic geography. Here the discussion will be limited to those contributions which appear to better fit with a view that considers "capabilities" as an endowment able to favour a middle income country technological and economic catching-up.

A crucial distinction between competences and capabilities has been introduced by von Tunzelmann and Wang (2003). Competences are understood as pre-set attributes of individuals, firms and organizations: competences are typically provided by the education and training systems and acquired through labour mobility. For example, one may think of firm's endowment of adequate skills as the necessary internal competences to obtain value from innovation investments (see Piva and Vivarelli, 2009b) ${ }^{2}$.

In a context of a developing middle-income country, this accumulation of competences can rely on the one hand on the supply provided by the education and training systems (both domestically and through studying abroad) and on the other hand on the labour mobility stemming from multinational enterprises (including spin-offs, that is the foundation of new firms by entrepreneurs formerly employed in a foreign-owned company).

\footnotetext{
${ }^{1}$ For instance, it has been shown that firms invest in R\&D not only to produce technological innovation, but also in order to create an internal capacity (see Cohen and Levinthal, 1989) able to absorb external knowledge coming from other firms and scientific institutions such as universities and public labs. In other words, firms that conduct their own R\&D are better able to identify, assimilate and exploit externally available knowledge.

${ }^{2}$ By the same token, the recruitment of university graduates or the spin-offs from larger innovative firms may be intended as carriers of the competences necessary to those firms that want to obtain values from external spillovers (see Acs et al., 1994; Audretsch and Vivarelli, 1996; Arrighetti and Vivarelli, 1999).
} 
Capabilities instead involve both internal and external learning and accumulation of new knowledge on the part of individuals, firms and organizations (see Bell and Pavitt, 1995; Hobday, 1995). Consequently, capabilities must be considered as the results of an adaptive learning process and so they are intrinsically "dynamic" (see Teece et al., 1997). Interestingly enough, the dynamic accumulation of capabilities is highly localised, giving rise to 'system' capabilities, i.e. referring to a specific spatial and industrial setting (see Iammarino and McCann, 2013).

Since capabilities are dynamically accumulated trough a continuous upgrading of new competences and through learning (see Arrow, 1962; Malerba, 1992; Dosi and Nelson, 2013), they show increasing returns and dynamic scale economies: more sophisticated are your initial competences, more you learn, more you can absorb external knowledge, and more capabilities you can accumulate in the long-run. Indeed, differences in the capacity of building adequate dynamic capabilities may explain the divide between countries that managed to escape from the MIT and countries that did not (think, for instance, to the role of education, training and learning in Japan in the '60s and '70s, Toyota being the most studied case, see Freeman, 1987). Similarly, particular regions within middle-income countries revealed to better exploit cumulative learning and the emergence of a knowledge critical mass able to make value from locally developed dynamic capabilities (see, for instance, the state of Bangalore in India).

In summary, specific competences are prerequisites, while dynamic capabilities originate that knowledge ready to be incorporated into new products and processes (see Zollo and Winter, 2002; von Tunzelmann and Wang, 2007; von Tunzelmann, 2009). From this point of view, adequate and updated competences and capabilities emerge as core assets for expanding the "product space" (see previous section) and escape from the MIT.

In concrete terms, capabilities are embedded in what the behavioural and evolutionary theories of the firm call "routines" (see Simon, 1955; Cyert and March, 1963; Nelson and Winter, 1982; Dosi, 1988): these are the procedures through which organizations make value from their capabilities in order to solve problems. In this framework, successful firms are characterized by updated and effective procedural routines (governing both the internal organization and the interaction with the external environment), while declining and failing firms are those that are unable to innovate, that is to renew their own routines, given the new challenges continuously posed by the market and the overall economic and institutional context.

It is important to recall that competences and capabilities pertain both individuals and collective organizations (see Dosi et al., 2000; Nübler, 2011 and 2014): indeed, in terms of a middle-income country's capacity to produce and absorb new knowledge, what emerges as crucial is the collective nature of learning and capabilities. From this point of view, successful routines are embedded into collective organizations (firms, networks and communities, institutions) where the "knowing how to do" is based on shared knowledge (often "tacit knowledge" not codifiable and not easily transferable, see Nelson and Winter, 1982; Dosi, 1988; Dosi and Nelson, 2013; Nübler, 2014).

Therefore, middle income countries willing to face the challenge to climb the knowledge ladder in order to avoid a MIT, should first of all increase their endowments in terms of preliminary competences, dynamic capabilities and collective routines. In this framework, education and training policies can be considered a conditio-sine-qua-non, in order to acquire a sufficient "absorptive capacity" able to make value from the available knowledge worldwide and trigger a further development of local dynamic capabilities (see Lall, 1992 and 2004). Here, the experience of those Asian countries that were able to overcome the MIT is illuminating: their massive investment in education and their consequent strong endowment in terms of skills and competences 
were the strong bases on which they started to accumulate those dynamic and collective capabilities which eventually allowed them to successfully catch-up richer economies. Indeed, evolutionary economists look at domestic capabilities - rather than market comparative advantages - as the basic endowments on the basis of which a developing country can engage a catching-up pattern of growth (see Dosi, et al., 1990; Cimoli et al., 2009).

However, the availability of competences and collective capabilities is a necessary but not sufficient condition for engaging into a successful catching-up and fostering a long-term productivity growth. In this respect, attention has now to be turned to the actual dynamics of technological progress, considered in its interaction with structural change.

\section{The key roles of technology and structural change: an interpretative framework in terms of technological taxonomies}

This section departs from the assumption that a middle income country had successfully built the preconditions for catching-up, in terms of competences and capabilities, as discussed in the previous section. If a country is "ready" to engage into technological progress and structural change, we have now to make clear how these changes develop and which are the strategies a middle income country can play in order to maximize its benefits from innovation. Here again, we depart from conventional mainstream economics, which consider technical progress as "manna from heaven" and refer to that innovation literature that - starting from Schumpeter $(1934,1942)$ has been able to endogenize technology in studying its intrinsic nature, drivers and consequences.

A first important stream of literature related to the drivers of innovation activity is represented by the demand-pull vs technology-push taxonomies.

Since Schmookler's (1962) seminal contribution, many authors have tested the hypothesis that demand drives the rate and direction of innovation. In this line, various theoretical and empirical approaches, both at the aggregate (see Schmookler, 1966; Scherer 1982; Kleinknecht and Verspagen, 1990; Geroski and Walters, 1995) and at the microeconomic level (see Brouwer and Kleinknecht, 1996 and 1999; Piva and Vivarelli, 2007 and 2009a) agree to consider demand and market growth as essential factors for boosting innovation activity based on increasing returns of scale, optimistic expectations and diminishing cash constraints.

In this context, a middle income country willing to escape the MIT should carefully take into account the internal and external sources of demand for local products, having in mind that innovation can be driven by demand evolution (for instance through an "export-led" dynamics). However, it is obvious that the technological content of "demand-pulled" innovation may substantially vary according to the specific sectoral/product development induced by a boosting demand (see Cimoli et al., 2010): in other words, the innovation consequences of an increase in the world/domestic demand for commodities would be different from an increase in the world/domestic demand for ICT-related products or for biotech products. In this perspective, the sectoral specialization of a middle income country also assumes a crucial importance (see below). 
At any rate, innovation is not only a market driven phenomenon: indeed, economic agents and policy makers may "push" technological advances and deliberately address the goal of increasing the rate of technological progress. In this context, innovation does not depend only on market signals (such as demand evolution or production factors prices) but is characterised by its own rules of development, as described in the well-known "technology-push" hypothesis. The first comprehensive discussion of this hypothesis was put forward by Mowery and Rosenberg (1979): their core idea is that the rate and direction of technological change is basically affected by advances in science and technology and by the availability of exploitable 'technological opportunities' (see Klevorick et al., 1995).

If such is the case, middle income countries can acquire higher degrees of freedom in foster domestic innovation as a way out from the MIT; far from being passive in front of an exogenous international division of labour that forces countries' sectoral and technological specialization, local public authorities and private economic agents can become active actors in pushing technological advances and consequent catching-up. These activities include public and corporate R\&D investments; public support to science and education; development of appropriate technological infrastructures; IPR regulation; cooperation agreements and JVs among private firms; university spin-offs; and so far so forth.

This active attitude may indeed be strategic in a medium-long term perspective; in fact, the technology-push theory highlights that $R \& D$ activities are dependent on their own rules of development: this means that technological progress is highly localized (Atkinson and Stiglitz, 1969) and path-dependent (see Rosenberg, 1982; David, 1985; Arthur, 1988). Closely related to these concepts, is the idea of a dominant 'technological trajectory' according to which innovation shows high degrees of cumulativeness (see Nelson and Winter, 1982; Dosi, 1988; Ruttan, 1997; Antonelli, 1998; Dosi and Nelson, 2013) and irreversibility and, as a result, is characterised by a higher level of persistence. In other words, any evolution of present innovative activities necessarily involves considering the role of previous innovative activities.

Here, another key technological taxonomy is the one put forward by Dosi (1982 and 1988), stating that a technological trajectory is the cumulative and irreversible process which has its roots inside a "technological paradigm" (see Dosi, 1982 and Dosi and Nelson, 2013) and develops alongside a process of "normal technical progress". If a change of paradigm represents a technological revolution (for instance the introduction and diffusion of ICT technologies) and is up to the most developed countries, technological change within a given trajectory is instead incremental and gradual and sets up a scenario where middle income countries may play an important role. In Dosi's view, both demand-pull and technology-push drivers jointly shape a given technological trajectory, in their interaction between each other and with a specific institutional setting.

In this context, for a middle income country the choice is between a passive acceptance of the role assigned (worldwide) by market forces and relative prices and a more active attitude aiming to participate to the shaping of the current technological trajectory through massive investments in knowledge activities (technology-push), and through selective and targeted demand-pull policies favoring sectoral diversification and product differentiation (see Cimoli and Dosi, 1995; Cimoli et al., 2009). In this perspective, those countries that will be able to play an active role in the prevailing technological trajectory will be able to escape from the MIT, while the others will remained trapped in something that it is not unavoidable, but strictly determined by the lack of those technology-push and demand-pull strategies able to foster a further technological and economic catching-up of the more advanced economies (think, for instance, to the contrasting specialization of the middle-income-trapped Latin American countries vs the Asian emerging 
economies: commodities on the one hand vs electronics and other high-tech sectors on the other, see Cimoli and Porcile, 2009).

An example of an active long-term strategy can be proposed using the well-known Pavitt's taxonomy (Pavitt, 1984). Overcoming the conventional distinction of economic activities based on the products produced, Pavitt put forward a framework where manufacturing firms are aggregated on the basis of their technological characteristics: 1) "science based firms" that are R\&D intensive, strictly connected with science (universities and scientific laboratories) and more prone to radical product innovation (think for instance to pharmaceutical and microelectronic firms); 2) "specialized suppliers" that are also R\&D intensive and devoted to introduce new and better quality products (think to advanced machineries); "scale intensive firms" that are mainly devoted to cost-cutting process innovation (think to large "fordist" firms such as car factories); 4) "supplier dominated firms" belonging to traditional sectors such as textile and clothing and introducing process innovation through the embodied technological change incorporated in machineries and components bought from firms belonging to the other three categories.

Having in mind the discussion above, a middle income country willing to avoid to remain framed into a MIT should actively search for original solutions to climb-up the technological and sectoral ladder moving from the "supplier dominated" category up to the scale intensive and specialized supplier ones and eventually - at least in some scientific niches - to the science based one. Indeed, the Asian countries which were able to escape from the MIT (first of all Japan in the '60s and '70s) are exactly those countries that managed to move up from a supplier dominated situation (with a dominant specialization in agriculture, traditional manufacturing sectors and non-tradeable basic services) to a much more diversified specialization characterized by a leading role of scale intensive firms (think about the automotive industry in Japan and South Korea), specialised suppliers (think about numerically controlled machineries in Japan) and eventually science-based firms (think about the role of microelectronics in Japan and all the other Asian NICs; see Amsden, 2001).

More recent taxonomies, extending what initially proposed by Nelson and Winter (1982) and Pavitt (1984) can also be illuminating in mapping a way out from the MIT based on a structural and technological upgrading of a DC’s economy.

In particular, another angle to look at the sectoral structure of a given economy can rely on the concept of "technological regime". Winter (1984) singles out an "entrepreneurial regime", where entry of innovative new firms is common, technological opportunities (in terms of possibilities open by science and academic institutions) are very high, market concentration is still limited and continuously affected by "creative destruction" (see Schumpeter, 1934; creative destruction being the continuous displacements of incumbent firms, established technologies and mature products by new firms, radical innovation and new products). In contrast, a "routinized regime" is characterised by entry barriers, lower technological opportunities, cumulative technologies, higher concentration rates and market power by the incumbent firms. To be concrete, nowadays sectors like bio-tech, medical instruments, information-intensive and health services belong to the entrepreneurial regime, while mature sectors like automobile, basic chemical, low-tech manufacturing and traditional services all belong to the routinized regime.

Malerba and Orsenigo (1995 and 1996) refined Winter's taxonomy, proposing the so-called "Schumpeter Mark I" sectors, opposed to the "Schumpeter Mark II" sectors. Indeed, Schumpeter (1934) put forward the entrepreneur founding a new innovative venture as the main driver of technological progress (Schumpeter Mark I or entrepreneurial regime), while Schumpeter (1939 and 1942) was much more aware of the key role of the systematic and cumulative innovation activities 
carried out by the large corporations, mainly within their R\&D departments (Schumpeter Mark II or routinized regime). According to the two Italian authors, Schumpeter Mark I sectors are characterized by a lower concentration of the innovative activities (that is technological opportunities are high and innovation is well spread around), a relatively small size of patenting firms, a large number of "de novo" innovators (that is new patenters) and a high likelihood of leapfrogging across the firms belonging to a given sector; Schumpeter Mark II sectors are characterized by the opposite features (see also Malerba et al., 2000).

Finally, Marsili (2001) and Marsili and Verspagen (2001 and 2002) proposed a further taxonomy that - extending Pavitt (1984) and taking into account the concept of entrepreneurial regime - can be considered as a bridging approach, combining what discussed so far (see also Dosi et al., 1995). The taxonomy put forward by Orietta Marsili single out five regimes that also correspond to five groups of sectors:

1) The "science based regime", where knowledge is based on advances in the "life sciences" and in "physical science", technological entry barriers are important (given the complexity and specificity of the technological opportunities), innovation is highly cumulative and mainly generating product innovation (examples being the pharmaceutical and the microelectronic industries).

2) The "fundamental-process" regime, which displays a medium level of technological opportunities, still high technological entry barriers and innovation still persistent but mainly addressed to process innovation (examples being the chemical and oil industries).

3) The "complex (knowledge) system" regime, where medium-high technologies are implemented in productions affected by important scale economies and where innovation is cumulative and addressed to both process and product innovation (examples being the aerospace and motor vehicle industries).

4) The "product-engineering" regime, where medium technologies are adopted in a context where innovative entry barriers and technological cumulativeness are relatively low and innovation is mainly of the product type (examples being the machinery and instruments sectors).

5) The "continuous-process" regime, where low technologies couple with low technological entry barriers, low persistence of innovation and a dominant role of process innovation, mainly embodied in capital goods and components coming from the previous four groups of sectors (examples being traditional manufacturing sectors like textiles, clothing, paper and printing, food and beverages).

Obviously enough, all the technological taxonomies discussed so far are clearly pointing out that "innovation" is not an homogeneous (strictly exogenous for many mainstream economists) phenomenon and should be understood in its deep interlinks with an economy sectoral structure. In other words, structural and technological change should be considered as highly interrelated and coevolving.

In particular, a middle income country eager to escape from the MIT, should address its technology investments and policies, taking into account the heterogeneity and sectoral peculiarities which characterize the intrinsic nature of innovation. 
For instance, the process innovation embodied in capital goods imported by richer countries (see next Section, point 1) may have an important role in sustaining the upgrading of those traditional sectors belonging to the "continuous-process" regime, but it unlikely may play a role in fostering structural change in terms of diversification and expansion of the product space (see Section 2). In contrast, attracting high-tech FDI and especially multinational R\&D labs (see next Section, point 3) may be of fundamental importance in the take-off of "science based regime" sectors. By the same token, innovative domestic new firms (see Section 6) may play a crucial role in entrepreneurial contexts (Schumpeter Mark I sectors) such as the "product-engineering” regime, but not in more routinized sectors (Schumpeter Mark I sectors) where only large and mature incumbents can have access to new technologies.

Having these considerations in mind, policies to escape from the MIT should be carefully shaped, targeted and tailored in order to maximize the benefits of the interaction between structural and technological change. Exactly the opposite scenario occurs when a middle-income country passively accepts to be embedded in a trap where international specialization, market forces through relative prices and technological inertia (path-dependency) constrains it into a static situation, where further economic growth is prevented by the lack of long-term strategies affecting both its sectoral structure and the domestic supply and demand of new technologies.

Indeed, the MIT is not an unavoidable outcome; having in mind the taxonomies discussed in this section, a middle income country can put forward a long-term strategy where tailored policies can be shaped on the basis of the different sectoral characteristics and where the same sectoral structure of the economy is not assumed as given but becomes itself a policy target (for instance, a middle income country may pursue the aim to gradually escape from the "continuous-process" regime in favour of the other four regimes discussed above).

In other words, middle income DCs should not pursue their development on the basis of their static "comparative advantages", but rather engage into long-term strategies addressed to achieve “absolute advantages” (see Dosi et al., 1990). In this respect, once again the Asian experience can be opposed to the Latin American one where most of the economies are still focusing on commodities and other supplier dominated ("continuous-process" regime) sectors, with very few attempts of structural and technological diversification towards the specialized-supplier and the science-based sectors (Brazil being a partial exception; see Cimoli and Porcile, 2009). Indeed, Cimoli et al., (2010) provide convincing evidence showing that the DCs that succeeded to escape from the MIT were those that were able to transform their industrial structure in favour of the hightech and higher demand elasticity sectors.

Obviously enough, acquiring competences and capabilities (see previous section) and moving up through the technological ladders set up by the taxonomies discussed in this section are two interrelated phenomena. On the one hand, adequate competences and capabilities are pre-requisites to enter that structural change that allows a country to move to a high-tech specialization (sciencebased and specialized suppliers sectors in Pavitt's terminology; emerging Schumpeter Mark I sectors in Malerba/Orsenigo's terminology; science based, complex and product-engineering regimes in Marsili's terminology); to fully exploit the options for differentiation and diversification (see Nübler, 2014); and to expand the product space jumping into sophisticated goods (see Section 2).

On the other hand - since capabilities are "collective" and "dynamic" and shaped by a continuous process of learning and accumulation of new and updated knowledge - moving into more advanced regimes provides those learning and technological opportunities which substantially increase the 
possibilities of acquiring new competences and capabilities and diffusing the ones already available within a country. From this point of view, advanced capabilities and high-tech regimes should be understood as interactive, co-evolving and mutually accelerating drivers of a long-term exit strategy from the MIT.

On the whole, combining the discussion put forward in Sections 3 and 4, we can come to the conclusion that dynamic capabilities, innovation and structural change are the key enabling factors for avoiding the MIT. However, middle income countries are embedded into a globalized world where trade, FDI and technology transfer have enormously increased their role. In this context, it is now time to turn our attention to the actual channels through which a middle income country can have access to knowledge.

\section{The different channels for knowledge upgrading in a globalized market}

If structural change and technological upgrading can make the difference among those countries still embedded in a MIT and those who managed to escape from it, this section will be devoted to answer to the following questions. Which are the channels through which a middle income country can climb the technological ladder? How globalization interact with technology transfer? How middle income countries can take advantage from the articulation of the global value chains within the different economic sectors?

The first vehicle for technological upgrading is obviously based on domestic investment in $R \& D$ and innovation (both public and corporate), a structural change favoring those sectors belonging to the most advanced categories within the taxonomies discussed in the previous section and a targeted innovation policy supporting both technology push and demand-pull innovation (see again the discussion in the previous section).

However, it is important to have in mind that a middle income DC has generally limited endogenous capabilities and knowledge (see Section 3); therefore, at least initially, it has to mainly rely on international technology transfer. In other words, its technological change is inherently connected with trade, foreign direct investments (FDI) and consequent international technologic transfer (see Acemoglu, 2003; Piva, 2003; Keller, 2004).

In addition, even in a later stage, a middle income country well-engaged in a catching-up pattern will be anyway inserted in different "global value chains" (see Hummels et al., 2001; Helpman, 2006), where international technological transfer maintains a crucial role.

In this framework, it is important to map the different channels through which globalization can act as a provider of new knowledge for the middle income economies.

1) Firstly, increasing globalization favors technological upgrading by increasing the international flows of capital goods, especially machineries (see Acemoglu, 2003). Indeed, there is much literature that finds that import and FDI inflows can in fact contribute to the technology transfer by providing middle income countries' local firms access to new embodied technologies and by 
creating opportunities for reverse engineering. In other words, the inflow of capital goods allows a middle income country to take advantage from the "embodied technological change" incorporated in machineries and components. Obviously enough, the receiving middle income country must possess the adequate capabilities (see Section 3) and a proper industrial structure (see Section 4) to allow an effective implementation of the imported technologies. If such is the case, the impact in terms of technological upgrading, productivity increase and ultimately economic growth can be substantial.

For instance, Coe and Helpman (1995) and Coe et al. (1997) find that foreign knowledge embodied in traded goods has a statistically significant positive impact on aggregate TFP in importing countries (either OECD countries or DCs). Focusing on DCs only, Mayer (2000) restricts the definition of import shares by considering only machinery and finds that in this case the impact of foreign R\&D is much greater. Similarly, Barba-Navaretti and Solaga (2002) look at the role of imported machinery in transferring embodied technological progress, focusing on the imports of machines from the EU to a sample of neighboring developing and transition countries in CentralEastern Europe and in the Southern Mediterranean; they find that imported machinery has a positive impact on total factor productivity and that the impact is greater the higher the technological complexity of the imported machinery.

Other studies used firm level database to examine imports as a mechanism for technological transfer and find that imports can in fact improve the technological capabilities of those firms well embedded in a global value chain (see for example, Blalock and Veloso, 2007).

Interestingly enough, a middle income DC can implement embodied technological change through a wide range of products. On the one extreme, it can take advantage from the importation of "mature" machineries (including second-hand capital goods, see Barba Navaretti et al., 1998) from more industrialized countries. On the other extreme, a middle income country can enjoy the "last comer" benefit of jumping directly on a relatively new technology (what Gerschenkron, 1962, labelled as the "benefit of backwardness"; see also Perkins and Neumayer, 2005); an example being the diffusion of mobile telecommunications in countries where the traditional telephone networks are limited to few urban areas.

By the same token, if the host middle income country is able to offer a proper industrial structure and a pool of adequate competence and capabilities (see previous sections), a foreign firm can opt for an high technology FDI (asset augmenting attitude), rather than an asset exploiting type of FDI (see Moncada-Paternò-Castello et al., 2011 and the discussion below).

Moreover, in addition to a direct effect through embodied technological change, imports and FDI inflows may generate technological spillovers in favor of the domestic firms which can absorb the new imported technologies through labor mobility, input-output relationships and reverse engineering (see Coe and Helpman, 1995; Coe et al., 1997). Here again, the presence of updated capabilities (see Section 3) and of a proper industrial and technological structure (see Section 4) are the pre-conditions to fully benefit from these indirect impacts of globalization.

2) Secondly, breaking into foreign markets allows firms originally operating in middle income countries to acquire knowledge of international best practice (the so-called "learning by export" hypothesis).

On the one hand, foreign buyers often provide their suppliers with technical assistance and product design in order to improve the quality of imported goods, and they may transmit to their suppliers 
located in DCs the tacit knowledge acquired from other suppliers located in advanced countries (Epifani, 2003). For instance, Newman et al. (2013) found convincing evidence that the export of intermediate goods may be a source of backward technology transfers that in turn can lead to productivity gains for domestic producers.

On the other hand, Yeaple (2005) shows that increased export opportunities make the adoption of new technologies profitable for more firms. Bustos (2005) builds a model upon the works of Yeaple (2005), while Melitz (2003) argues that trade liberalization reduces variable export costs and makes adoption of new technologies profitable for more firms.

Moreover, Verhoogen (2007) argues that trade leads to an upgrading of average product quality in exporting plants; in particular, he finds that the "quality-upgrading hypothesis" is relevant for a middle income country such as Mexico. This idea is also pursued by Fajnzylber and Fernandes (2009) studying Brazil - who point out that exporters may be pressured by their foreign clients to produce according to quality standards that are higher than those prevailing in the domestic market.

In sum, technological catch-up may be induced by exporting to richer countries both through substituting/replacing outdated technologies in the exporting sectors and through the development of entirely new businesses characterized by process and product innovation addressed to satisfy a more sophisticated demand coming from the richer countries (see Keller, 2004).

3) Thirdly, technological up-grading can occur in a direct way through the outsourcing of knowledge intensive activities - such as R\&D labs - from richer countries to middle income countries. Although relatively recent, this phenomenon is fast growing and implying obvious and relevant effects on the capability building capacity, the productivity evolution and ultimately the economic growth of the host countries (see Moncada-Paternò-Castello et al., 2011).

Indeed, over the last two decades, the international re-allocation of the global value chain has increasingly shifted towards the 'unbundling' of activities previously vertically integrated and locally concentrated (see Hummels et al., 2001; Hanson et al., 2005; Helpman, 2006; Rugman et al., 2010). Nowadays, this unbundling trend also concerns knowledge intensive activities - such as R\&D and innovation ${ }^{3}$ - which were previously considered 'core activities' to be retained by companies' headquarters (see Grossman and Helpman, 1991; Florida, 1997; Chung and Yeaple, 2008). This (accelerating) trend has been favored by different factors, such as: (1) the nature of ICT and new technologies which can be split into different stages, characterized by different enabling knowledge (e.g. 'open innovation' in the software industry); (2) the increasing importance of R\&D cooperation across firms (see Veugelers, 1997; Cassiman and Veugelers, 2002; Piga and Vivarelli, 2003 and 2004), which renders more likely and profitable the emergence of R\&D complementarities between firms located in different areas of the world; (3) the increasing availability of skilled labor and capabilities (see Section 3) in emerging middle income countries such Brazil, Russia, India, China and the EU new member states (see Wood, 1994; Wood and Ridao-Cano, 1999; Meschi and Vivarelli, 2009).

From an empirical perspective, a survey presented by the EIU (2004) revealed that when managers were asked where they would spend the most on R\&D in the next three years, two emerging countries stood out: China and India (39\% and 28\%, respectively). More specifically, an UNCTAD

\footnotetext{
${ }^{3}$ And patenting activity, as well (see Montobbio and Sterzi, 2013).
} 
(2005) survey of the largest R\&D spenders among multinational enterprises revealed that China was the third largest global destination, behind the US and UK; and India was sixth.

Looking deeper at the drivers of locating corporate R\&D activities, Thursby and Thursby (2006) stress four outstanding factors: output market potential, quality of R\&D personnel, university collaboration, and intellectual property protection. Further, for companies locating in middle income countries, the growth potential of the local market and the quality of R\&D personnel appear particularly important (see also Añon Higón, et al., 2011).

As a matter of fact, local capabilities and domestic innovation capacity (see previous Sections 3 and 4) - which do play a role in the fruitful importing of embodied technological change and in the learning by export (see previous points) - are a fortiori crucial in attracting foreign knowledgebased investments.

On the whole, middle income countries engaged in a technological catching-up able to overcome the MIT, should be able to reach a good match of their own capabilities, domestic innovation and industrial structure with the three channels of technology transfer discussed above (see Montobbio, and Rampa, 2005).

In particular, higher domestic capabilities and an advanced industrial structure (for instance, in terms of Pavitt's taxonomy, see previous Section 4) maximize the absorptive capacity able to get benefits from foreign technologies. In this context, globalization patterns should not be taken as something exogenous and given once for all; on the contrary, middle-income countries should concentrate their efforts to shape both import liberalization and export-led initiatives in order to maximize a fruitful evolution in terms of structural change and technological upgrading. For instance, through a policy attracting FDI in the science-based sectors or through public support favoring "learning by export" in the more advanced categories of sectors according to the taxonomies discussed in the previous section (think, for instance, to the possible roles of statefinanced export consortia).

In sum , globalization should not be considered as an external constraint that hinders the possibility - for an open middle income country - to upgrade its economic structure towards more technologically-advanced regimes (see Section 4). On the contrary, globalization should be considered as an opportunity to climb the structural and technological ladder. Here again, capability building, structural and technological change and globalization patterns should be understood as coevolving phenomena, where feedbacks, circular causation and cumulative super-additive effects may definitely make the difference in allowing a middle income country to escape from the MIT.

\section{The potential for innovative entrepreneurship}

This section opens a relatively unexplored perspective, namely the possible role of innovative entrepreneurship in fostering structural change and innovation, which have been singled out as key assets in overcoming the MIT. Indeed, structural changes such as the upgrading of the sectoral structure of a given economy (see Section 4) may occur both through the diversification of the existing firms or through the birth of entirely new ventures. By the same token, innovation and 
product differentiation can be introduced either by the incumbent companies or by innovative startups.

For instance, Baumol et al. (2007), point out that, over the last 15 years, productivity growth in advanced economies has been due in the main to the development of innovative entrepreneurial companies, such as Microsoft, Intel, eBay, Amazon, Google, Apple, Walmart among others. By the same token, Czarnitzki and Delanote (2013) found convincing evidence that young innovative firms grow more than other firms both in terms of sales and employment ${ }^{4}$.

In more general terms, according to Schumpeter (1934), entrepreneurship is a driving force of innovation, and more generally an engine for economic development (see Audretsch et al., 2006; Koellinger and Thurik, 2012; and, for a comprehensive survey, Van Praag and Versloot, 2007). As detailed by Wennekers and Thurik (1999) and Dejardin (2011), new firm formation may play a crucial role in fostering competition, inducing innovation and fostering the emergence of new sectors. Ultimately, new firms may substantially contribute to job creation, provided that the net effect of new entrants brings about overall market growth (see Malchow-Møller, et al., 2011).

However, the relationship between the rate of new firm creation, innovation and economic development is heterogeneous across countries. The distinction between advanced and developing countries is especially important in this respect. Such heterogeneity can be better understood when shifting the focus to the micro foundations of entrepreneurship. Since the seminal contribution by Baumol (1990; see also Baumol, 2010) we have known that 'Schumpeterian' innovative entrepreneurs' coexist with 'defensive and necessity entrepreneurs', the latter being those who enter a new business not because of market opportunities and innovative ideas, but merely because they need an income to survive.

For obvious reasons, this kind of 'survival-driven' self-employment is particularly diffused in middle income and low income DCs (Naudé, 2009 and 2010; Desai, 2009; Yamada, 1996), where poverty and lack of formal opportunities in the wage sector often push a large number of people into 'entrepreneurial' activities ranging from street vending to traditional and personal services (in most cases within the informal sector of the economy, see Ihrig and Moe, 2004; Maloney, 2004; Sonobe, et al., 2011) ${ }^{5}$.

Moreover, the empirical evidence concerning industrial dynamics also makes one more skeptical on the progressive potentialities of business start-ups. Firstly, survival rates for new firms are strikingly low: the available econometric evidence shows that more than $50 \%$ of new firms exit the market within the first five years of activity (see Dunne, Roberts and Samuelson, 1988 and 1989; Reid 1991; Geroski, 1995; Mata, et al., 1995; Audretsch and Mahmood, 1995; Audretsch et al., 1999a

\footnotetext{
${ }^{4}$ Indeed - in seeking to account for the persistent gap that exists between the EU and the US in terms of innovative performance and productivity - scholars and policy makers often refer to the European weakness regarding young innovative companies (YICs; see Cincera and Veugelers, 2010). In fact, in Europe, young companies have lower capacities to innovate and higher rates of early failure (see Bartelsman et al., 2004; Santarelli and Vivarelli, 2007; Vivarelli, 2013b), whereas the US economy has been able to generate a steadily increasing flow of young innovative firms that not only survive but which develop new products at the core of emerging sectors. For these reasons, many EU countries have implemented policies to support the creation and growth of YICs, focusing - for instance - on facilitating their access to funding and providing support for the commercialization of innovation (see EC-DG ENTER, 2009; Schneider and Veugelers, 2010).

${ }^{5}$ The prevalence of 'survival driven' entrepreneurs in DCs is often associated to the choice to stay small and informal, rather than participating to the formal sector of the economy (see Section 3; Klapper, et al., 2010; Desai, 2009). This is one of the reasons why the effects of entrepreneurship on economic performances of DCs appear to be problematic.
} 
and 1999b; Johnson, 2005). Secondly, entry and exit rates are significantly correlated (what is called "turbulence", see Beesley and Hamilton, 1984); this is one of the uncontroversial 'stylized facts' of the entry process according to Geroski (1995, p. 424), who pointed out that the "mechanism of displacement, which seems to be the most palpable consequence of entry, affects young, new firms more severely” (see also Baldwin and Gorecki, 1987 and 1991). Indeed, entry and exit rates have been found to be positively correlated across industries in both OECD countries (see Bartelsman, et al., 2005) and in DCs (see Bartelsman, et al., 2004).

These evidences cast some doubts on the alleged role of entry as a vehicle for innovation, productivity growth and employment generation. A fortiori, one should be particularly cautious in seeing entrepreneurship in general as one of the main drivers of technological upgrading and structural change in a middle income country aiming to escape from the MIT.

However, if the underlying motivation to start a new firm is linked to innovative projects, then a better post-entry performance should be expected. Empirically, this seems to be the case. In fact, a propensity for innovation emerges in general as a firm's growth driver (see, for instance, Freel, 2000; Coad and Rao, 2008; Altindag, et al., 2011; Corsino and Gabriele, 2011) and specifically as a positive predictor of survival and an above-the-average post-entry performance of newborn firms (see Arrighetti and Vivarelli, 1999; Esteve-Pèrez, et al., 2004; Raspe and Van Oort, 2008).

Consistently with the discussion above, Cefis and Marsili (2006) found convincing evidence of an 'innovation premium' in survival time: using Pavitt's (1984) taxonomy, they showed that young firms (less than four years old) in the 'science-based' and 'specialized supplier' sectors were characterized by significantly higher chances of survival than firms in other sectors ${ }^{6}$.

However, the impact of innovation on post-entry performance of newborn firms is strictly related to sectoral differences and ultimately to the differential patterns of specialization of countries. Actually, entrepreneurial dynamics in DCs is more likely to occur in sectors which are far from the technological frontier; therefore, the prevalence of traditional and mature sectors make these contexts less fertile for innovation-driven entrepreneurship. According to Siqueira and Bruton (2010), high-technology entrepreneurship in emerging economies is subject to greater resource constraints and higher levels of informality than in advanced countries.

Nevertheless, Santarelli and Tran (2011) studied entrepreneurship in Vietnam using a panel of regional-level data for 61 provinces over the period 2000-2008; among other outcomes, the authors found that an innovative climate (proxied by the share of technical/R\&D personnel in the province) significantly and positively affects the regional net entry rate. As far as post-entry performance is concerned, in a study investigating 947 small and medium entrepreneurial firms in eleven SubSaharan African countries, Goedhuys and Sleuwaegen (2010) found that the innovative capability (proxied by a dummy for the introduction of new products) increases a firm's annual employment growth by $2 \%$ on average.

To sum up, while new firm formation in general cannot be necessarily seen as a vehicle of structural change and technological progress, innovative entrepreneurship may play a role within a middle income country willing to offset a possible MIT. However - since the bulk of start-ups in a DC is made by traditional activities and services (defensive" or "necessity" entrepreneurship such as street vendors), often concentrated in the informal sectors and doomed to early failure - policies aiming to

\footnotetext{
${ }^{6}$ More specifically, Cefis and Marsili (2005) have shown that being an innovator enhanced the expected time of survival by $11 \%$ compared with non-innovator counterparts.
} 
foster entrepreneurship should be extremely cautious. In particular, 'erga-omnes' entry subsidies should be discarded in favor of selective and targeted measures addressed to the more promising potential entrepreneurs, such as those characterized by a superior human capital (here again, the presence of adequate competences and capabilities emerge as a necessary pre-condition, see Section 3) and operating in the more advanced sectors according to the taxonomies detailed in Section 4.

Indeed, what discussed in Sections 3 and 4 can provide a sort of guideline for an economic policy targeted to foster entrepreneurship not "per sé", but as a vehicle to foster and accelerate a structural change in favor of those "regimes" that can be considered the engines for innovation, capabilitybuilding and eventually productivity growth and catching-up. For instance, innovative entrepreneurship in the "science-based" regime should be supported by public authorities, especially in terms of training courses for potential founders eager to acquire those competences and capabilities (see Section 3) that are necessary for starting new firms in the high-tech sectors.

Finally, focusing on domestic entrepreneurship in the middle income DCs is also a way to underline that catching-up should not only based on technological transfer, FDI attraction and spillovers (see Section 5), but also driven by local innovative new enterprises (see Amsden, 2009; Hobday and Perini, 2009; for an extensive discussion of the role of entrepreneurships in the DCs, see Vivarelli, 2012).

\section{The possible impact of technological upgrading in terms of jobs and skills}

While the previous sections show that structural change, innovation and entrepreneurship - in their interaction with globalization - can be considered the ways out from the MIT, the consequences in terms of jobs and skills cannot be taken from granted and may be controversial. For instance, structural change and technological upgrading can foster productivity growth, enhance competitiveness and eventually economic growth on the one hand, but they may exhibit a laborsaving nature on the other hand, the final outcome in terms of jobs being dependent on which of the two forces turns out to be dominant. In what follows, we briefly give account of the two strands of economic literature respectively devoted to investigate the quantitative and the qualitative impacts of new technologies upon employment.

1) Technological change allows to produce the same amount of output with a lower amount of production factors, namely capital and labor. However, what textbooks represent as technological change is only the "direct" effect of innovation; indeed, the economic discipline - since its foundation - has tried to dispel the concerns about the direct harmful effects of technological change, pointing out the market mechanisms able to counterbalance the direct impact of process innovation (for an extensive analysis, see also Vivarelli, 1995, chaps.2 and 3; Petit, 1995; Vivarelli and Pianta, 2000, chap. 2; Piva and Vivarelli, 2004; Pianta, 2005; Vivarelli, 2013a).

Five main compensation mechanisms work to offset technology's labor-saving effects through: (1) additional employment in the capital goods sector where new machines are being produced, (2) decreases in prices resulting from lower production costs on account of technological innovations, (3) new investments made using extra profits due to technological change, (4) decreases in wages as a consequence of the initial job losses, and (5) new products created using new technologies. 
Obviously enough, compensation mechanisms can be hindered - or even annihilated - by the existence of important market failures and institutional drawbacks. For instance, labor-saving technologies can spread around in the capital goods sector as well, so limiting the power of the compensation " via new machinery"; moreover, the new machines can be implemented simply by substituting the obsolete ones (scrapping), involving no compensation in jobs. Similarly, the effectiveness of the mechanism "via decrease in prices" depends on the hypothesis of perfect competition and on the value of the demand elasticity (see Sylos Labini, 1969, p. 160). By the same token, the compensation mechanism "via new investments" also relies on the strong assumption that the accumulated profits due to technical change are entirely and immediately translated into additional investments, while it should be taken into account that the economic agents' expectations can imply a delay in the translation of additional profits into "effective demand" (see Pasinetti, 1981). Moreover, the intrinsic nature of the new investments does matter; if these are capital-intensive and labor-saving, compensation will be particularly limited. Also the mechanism "via decrease in wages" is controversial: on the one hand, a decrease in wages can induce firms to hire additional workers, but - on the other hand - the decreased aggregate demand lowers the employers' expectations and so they tend to hire fewer workers. Finally, albeit new products can be considered the more powerful way to counterbalance labor-saving process innovations, different “technological paradigms" (see Dosi, 1982; Dosi and Nelson 2013; see also Section 4) are characterized by different clusters of new products which in turn have very different impacts on employment ${ }^{7}$.

Turning our attention to the main strategies singled out in this study as the most effective exit strategies from the MIT, new technologies and structural change may well involve productivity gains which can be harmful to employment. In particular, the possible dominant role of the imported embodied technological change implying labor-saving process innovation can drastically decrease the domestic demand for labor (see Section 5, point 1; see Lee and Vivarelli, 2004 and 2006b).

In more detail, when "total factor productivity" increases in a middle income country as a consequence of imported and domestic technologies, the employment enhancing competitive effect has to be compared with the direct labour-saving effect of such technologies (see Vivarelli, 1995; Coe et al., 1997; Mohnen and Hall, 2013). The final outcome cannot be assessed a priori. On the whole, as discussed in Taylor (2004), the final employment outcome depends on the balance between labor productivity gains and output growth. Consistently, in determining the final employment outcome, the effectiveness of price and income compensation mechanisms and their possible drawbacks discussed above are obviously crucial in the particular case of middle income DCs, as well (see Hall and Heffernan, 1985).

2) Beyond the quantitative effect of innovation on the number of employees, it is also important to single out and investigate the qualitative effect of technological and structural change. Indeed, the literature focusing on the complementary between technological change and skilled labor has put forward the so-called "skill biased technological change" hypothesis (SBTC); initially proposed by Griliches (1969) and Welch (1970), this hypothesis supports the view that new technologies - to be implemented effectively and efficiently - require suitable skills.

The first to explore SBTC empirically were Berman, et al., (1994) who provided evidence for the existence of strong correlations between within industry skill upgrading and increased investment in

\footnotetext{
${ }^{7}$ As a matter of fact, in different historical periods and different institutional frameworks, the relative balance between the labor-saving effect of process innovations and the labor-intensive impact of product innovations can considerably vary.
} 
both computer technology and R\&D in the U.S. manufacturing sector between 1979 and 1989. Stemming from this seminal contribution, several further empirical studies have confirmed the occurrence of a widespread SBTC in the US (see Autor, et al., (1998); UK (Machin, 1996); France (see Caroli and Van Reenen, 2001); Spain (see Aguirregabiria and Alonso-Borrego, 2001); Italy (see Piva, et al., 2005) and other OECD countries (see Machin and Van Reenen, 1998).

While most of the literature on the qualitative employment impact of technological change is centered on the developed economies, in recent times some attention has also been devoted to the specificities of the middle-income and low-income DCs.

According to the mainstream economic theory, in the DCs technological progress and globalization are supposed to have opposite effects in terms of demand for skills (for an extensive analysis, see Lee and Vivarelli, 2004, 2006a and 2006b): on the one hand, new technologies shift the labor demand in favor of more skilled workers; on the other hand, the Heckscher-Ohlin-Stolper Samuelson (HOSS) mechanism predicts that a DC trading with skill-abundant richer economies should specialize in the production of unskilled-labour-intensive goods and therefore experience a relative increase in the demand for unskilled labour.

In contrast, if the HOSS assumption of homogeneous production functions and identical technologies between countries is relaxed, international openness may facilitate technology transfer from advanced to developing countries through the different channels discussed in Section 5, implying that globalization and technological change are complementary rather than alternative mechanisms, both resulting in an increase in the demand for skilled workers (for more extensive analyses, see Vivarelli, 2004 and Lee and Vivarelli, 2006b).

Robbins (1996 and 2003) and Robbins and Gindling (1999) call the effect of in-flowing technology resulting from trade liberalization the "skill-enhancing trade (SET) hypothesis". Their idea is that trade accelerates the flows of physical capital (and embodied technology) to the South, inducing rapid adaptation to the modern skill-intensive technologies currently used in the North.

The available empirical evidence appears to reject the HOSS predictions and to support the SET hypothesis. For example, Berman and Machin (2000 and 2004) found that SBTC had been transferred rapidly from the developed world to at least the middle-income DCs. Meschi and Vivarelli (2009) - once they had disaggregated trade flows according to their areas of origin/destination - found a significant inequality-enhancing effect in middle-income DCs due to trade with more advanced countries, possibly related to technological transfer and skill-enhancing trade. Almeida (2009) reached very similar conclusions using firm-level data for East Asia ${ }^{8}$.

The evidence from country-specific studies is also pointing out the links between trade, FDI, technology transfer and skill-upgrading. For instance, Hanson and Harrison (1999), using data on Mexican manufacturing plants, found that firms receiving FDI acquire technology through licensing agreements or imported materials, and tend to hire more skilled workers (see also Feenstra and Hanson, 1997). Similarly, Fajnzylber and Fernandes (2009) found that increased levels of international integration were associated with an increased demand for skilled labor in a crosssection of Brazilian firms. Görg and Strobl (2002) analyzed a panel of manufacturing firms in Ghana over the '90s; their estimates revealed that while the purchase of foreign machinery for

\footnotetext{
${ }^{8}$ By the same token, Conte and Vivarelli (2011), using a direct measure of embodied technological transfer, found that imported skill-biased technological change is one of the determinants of the increase in the relative demand for skilled workers in DCs.
} 
technological purposes significantly raised the relative demand for skilled labour, a greater participation in world markets via exporting activities did not have any effect.

Other papers have instead underlined the skill-enhancing effects of exporting activity, which makes the adoption of new technologies profitable for more firms (see Yeaple, 2005), induces quality upgrading (see Verhoogen, 2008; Fajnzylber and Fernandes, 2009) and offers opportunities to acquire knowledge of international best practice (see Bigsten et al., 2004; see Section 5, point 2).

Finally, at least for middle income countries, together with imported technologies and exports, domestic R\&D and innovation may play a relevant role, as it is the case for the most advanced countries (see previous sections). For instance, Meschi et al., (2011) showed that SET was an important factor in explaining the rise of the skilled labour cost share, but together with domestic R\&D. By the same token, Araújo et al., (2011) also found evidence in support of both the role of SET and domestic technology in determining the skill-upgrading trend of the Brazilian manufacturing labor force.

Summing-up, while middle income countries must engage in structural change, technological progress and globalization in order to avoid the risk of a MIT, the social consequences in terms of jobs, skill-bias and inequality may be controversial. On the one hand, an overall labour-saving impact of the new domestic and imported technologies cannot be excluded and - on the other hand - globalization and new technologies can likely involve an increase in the demand for skills and possibly an increase in wage and income inequality. Given these possible adverse employment and distributional effects, a crucial role has to be attributed to labor and education policies, able to maximize job creation and to overcome a possible skill shortage (see next section).

However, employment-friendly policies can combine the need for structural and technological change with the aim to create new and better jobs. For instance, a strong investment in R\&D (in order to sustain the sectors belonging to the science-based regime, see Section 4) is likely to imply as a positive secondary effect - an increase in employment and particularly in skilled employment (in fact, R\&D expenditures are strictly related to product innovations that are job-creating, see the discussion above; for empirical studies showing the employment friendly nature of $R \& D$ investments, see Bogliacino and Vivarelli, 2012 and Bogliacino et al., 2012). By the same token, an industrial policy targeted in favour of the science based and product-engineering regimes (in Marsili's terminology) is also likely to increase the demand for labor, since those regimes are characterized by a dominance of product innovation (see Freeman et al., 1982; Freeman and Soete, 1987 and 1994; Vivarelli et al., 1996).

\section{Conclusions and policy implications}

The main message contained in this study is that capability building, structural change, innovation and entrepreneurship should be considered as the most important exit strategies from the MIT. Some policy suggestions have been already put forward in the previous sections; here, we will briefly single out again those policy perspectives that appear particular important in facilitating the active enrolment of a middle income DC into such exit strategies. 
- As far as competences and capabilities are concerned, it clearly emerges a role for education policy on the one hand and for labor market policy on the other.

Education policies should be addressed to provide the necessary basic competences on the basis of which the future labor force can build proper and updated capabilities. If such is the aim, middle income DCs should not only increase their average years of schooling, but also shape their educational attainment structures to maximize the opportunities to develop social and collective capabilities. From this point of view, it has been showed that middle income countries that successfully engaged in catching-up (like South Korea, Taiwan, Hong Kong, Israel) were those that have been able to strength their lower and upper secondary education levels (see Nübler, 2013, Figure 4).

Labor market policies should make labor mobility easier (both among firms and from scientific institutions towards private companies), in order to maximize the sharing of the available knowledge and make capabilities strongly collective (see Section 3). In this context, labor mobility from foreign firms should also be encouraged, also in the form of entrepreneurial spin-offs.

- With regard to structural and technological change (see Section 4), an impressive important role opens up for industrial and innovation policies. Far from the mainstream economics conventional wisdom considering industrial policies either useless or even harmful, the discussion put forward in this study supports an opposite view. Indeed, middle income countries willing to escape from the MIT should actively engage in supporting structural change and innovation as was - and it still is - the case for the most industrialized countries (see Mazzucato, 2011). As properly discussed by Cimoli et al., (2009, chapter 20), State intervention can (must) play a crucial role both in capability building (see previous point) and in fostering a structural and technological change addressed towards the most advanced regimes (see the taxonomies and the discussion proposed in Section 4).

In this framework, industrial and innovation policies should targeted those sectors which are characterized by advanced technological contents, higher demand elasticity at the world level and wider learning opportunities. Therefore, policies should be highly selective - in order to avoid government failures such as duplications, substitution effects and deadweight effects $^{9}$ - and target advanced sectors and technologies, in order to create new absolute advantages, rather than to specialize in the existing comparative advantages (as prescribed by orthodox international economists).

- Turning our attention to globalization, here again trade liberalization and comparative advantages should not be taken as the starting point for an effective exit strategy from the MIT. In contrast - as was the case of the successful Asian countries escaping from the MIT in the second half of the XX century - a middle income DC should not only be concerned with attracting FDI and foreign technologies but should also promote policies for the development of domestic enterprises able to engage in sophisticated export baskets and foster local entrepreneurship able to compete in the international markets (see next point).

\footnotetext{
${ }^{9}$ A substitution effect occurs when a policy intervention (such as a subsidy or a tax relief) favor a poorly performing agent (for instance a firm), crowding out a possibly more efficient one; a deadweight effect occurs when public money is given to an efficient agent that would have performed well in any case, even without the subsidy.
} 
In this framework, industrial and innovation policies are important again in favoring an effective (and possibly creative, see Antonelli, 2006) implementation of foreign technologies and in maximizing the benefits from the so-called "learning by export". Last but not least, middle income countries should shape specific policy schemes to attract hightech FDI and especially multinational R\&D labs, so fully exploiting the opportunities provided by the recent trends in the unbundling of the international value chains.

- As mentioned above, domestic enterprises and particularly new ventures may play an important role in the catching-up, both in terms of producing and absorbing new capabilities and knowledge. In this respect, entrepreneurial policies are welcome, provided they are closely targeted to the innovative new firms, possibly in the high-tech and emerging sectors. As discussed in Section 6, most of entrepreneurs in the DCs are of the defensive types and cannot play any role in fostering productivity growth; differently, innovative entrepreneurs should be helped in developing their business ideas.

- As discussed in Section 7, structural change and technological upgrading do not assure, per sé, either job-creation or equality; rather, the current technological trajectory is likely to show both a labor-saving and a skill-biased nature, so possibly implying unemployment and increasing inequality. From this point of view, policies should shape the previously discussed patterns of structural change, innovation and globalization, in order to maximize their job creation potentialities and minimize their impact in terms of inequality. Here, education policies (see first point) remain crucial, since an adequate supply of skills can avoid the "skill shortage" and so job-losses and inequality that would be associated to a skill-biased technological change (either domestic or imported) not encountering an adequate local supply of skills. Finally, the targeted industrial and innovation policies discussed above should have their employment impact in mind and favor R\&D based and product innovators, since the expansion of the product space (see Section 2) is intrinsically labor friendly, while process innovation can have an harmful employment impact (see Section 7).

Obviously enough, all the single policies listed above have been singled out for sake of simplicity, but should be understood as belonging to a unified framework. As stated several times in this contribution, collective capabilities, structural change and technological progress must be considered interrelated phenomena which jointly and simultaneously co-evolve. If such is the case, policies should also be interpreted as a unified - although articulated - support to the dynamic evolution which can sustain a successful catching-up.

In more general terms, the policy packages discussed above, should be intended as strategies to obtain a good "match" (see Perez, 1983; Freeman and Perez, 1988) between technological opportunities, structural change and the institutional setting. In Carlota Perez's words, a good match between technological change and institutions is in fact a pre-condition for productivity growth and eventually for economic growth. Moreover, if we take into account that capabilities, structural and technological change and globalization continuously co-evolve, the need for an effective institutional framework emerges as even more crucial nowadays. In this framework, institutions can be important carriers of collective capabilities, can shape structural and technological transformations and can address the globalization process towards the most advanced patterns of trade and FDI inflows (see above). 
However, policy intervention should not be limited to provide adequate infrastructures, to enforce IPR, to make the labor market more flexible and bureaucratic procedures faster and less corrupted (see Agenor et al., 2012; Jankowska et al., 2012; Aiyar et al., 2013). This emphasis on "soft", "enabling" policies is part of the conventional wisdom so widespread among mainstream economists and inside most of the international organizations. The view proposed in this contribution strongly departs from this extremely cautious and market-oriented approach, in favor of a much more active role of the policy makers in shaping the current patterns of globalization, structural change and technological progress. Indeed, taking seriously the lessons from Japan, Asian NICs and nowadays China means to recognize that exiting from the MIT is basically a strategic long-term policy target that requires massive investments in education, training and $\mathrm{R} \& \mathrm{D}$ expenditures and a strong and selective support to public and private companies - both existing firms and new entrepreneurial ventures - operating in the emerging and innovative sectors and in the more advanced importing and exporting niches.

Indeed, these "hard policies" should be understood as the main pillars of an advanced "national system of innovation"10 (see Freeman, 1987; Lundvall, 1992; Nelson, 1993) able to foster productivity growth and economic development: only those middle income countries which will be able to actively and properly shape their own national system of innovation will escape from the MIT.

\footnotetext{
${ }^{10}$ A "national system of innovation" is made by those national interacting organizations and institutions (firms with their suppliers and customers; banks and financing agents; education and training institutions, national and regional policy makers) which jointly contribute to produce knowledge and innovation within a given country and to increase its absorptive capacity in implementing knowledge produced elsewhere in the world.
} 


\section{REFERENCES}

Abramovitz, M. (1986), Catching Up, Forging Ahead, and Falling Behind, The Journal of Economic History, 46, 185-406.

Abramovtiz, M. (1992), Catch-Up and Convergence in the Postwar Growth Boom and After, in: Baumol, W. J., Nelson, R., and Wolff, E. N. (Eds.): Convergence of productivity: Cross-country studies and historical evidence, Oxford, Oxford University Press, 86-125.

Acemoglu, D. (2003), Patterns of Skill Premia, Review of Economic Studies, 70, 199-230.

Acs, Z.J., Audretsch, D.B. and Feldman, M.P. (1994), R\&D Spillovers and Recipient Firm Size, Review of Economics and Statistics, 7, 336-40.

Agénor, P.R. and Canuto, O. (2012), Middle-Income Growth Traps, World Bank Policy Research Working Paper 6210, Washington DC, World Bank.

Agénor, P.R., Canuto, O and Jelenic, M. (2012), Avoiding Middle-Income Growth Traps, Economic Premise ,No. 98, Washington DC, World Bank.

Aghion, P. and Howitt, P., (1998), Capital Accumulation and Innovation as Complementary Factors in Long-Run Growth, Journal of Economic Growth, 3, 111-30.

Aguirregabiria, V., and Alonso-Borrego, C. (2001) Employment Occupational Structure, Technological Innovation, and Reorganization of Production, Labor Economics, 8, 43-73.

Aiyar, S., Duval, R., Puy, D., Wu, Y. and Zhang, L. (2013), Growth Slowdowns and the Middleincome Trap, Working Paper 13/71, Washington DC, International Monetary Fund.

Almeida, R. (20099, Openness and Technological Innovation in East Asia: Have They Increased the Demand for Skills? IZA Discussion Papers, 4474, Bonn, IZA.

Altindag, E., Zehir, C. and Acar, A.Z. (2011), Strategic Orientations and their Effects on Firm Performance in Turkish Family Owned Firms, Eurasian Business Review, 1, 18-36.

Amsden, A.H. (2001), The Rise of "The Rest": Challenges to the West From Late-Industrializing Economies, Oxford, Oxford University Press.

Amsden, A.H. (2009), Nationality of Firm Ownership in Developing Countries: Who should 'Crowd Out' whom in Imperfect Markets, in M. Cimoli, Dosi, G. and Stiglitz, J.E. (Eds), Industrial Policy and Development: The Political Economy of Capabilities Accumulation, Oxford, Oxford University Press., 470-506.

Añón Higón, D., Manjón Antolín, M. and Mañez, J.A. (2011), Multinationals, R\&D, and Productivity: Evidence for UK Manufacturing Firms, Industrial and Corporate Change, 20, 64159.

Antonelli, C. (2006), Diffusion as a process of creative adoption, Journal of Technology Transfer, 31, 211-226. 
Antonelli, C. (1998), The Dynamics of Localized Technological Changes. The Interaction between Factor Costs Inducement, Demand Pull and Schumpeterian Rivalry, Economics of Innovation and New Technology, 6, 97-120.

Araújo, B.C., Bogliacino, F. and Vivarelli, M. (2011), Technology, Trade and Skills in Brazil: Some Evidence from Microdata, Revista CEPAL/CEPAL Review, 105, 157-71.

Arrighetti, A. and Vivarelli, M. (1999), The Role of Innovation in the Postentry Performance of New Small Firms: Evidence from Italy, Southern Economic Journal, 65, 927-39.

Arrow, K. (1962), The Economic Implications of Learning by Doing, Review of Economic Studies, 29, 155-73.

Arthur, W.B. (1988), Competing Technologies: An Overview, in: Dosi, G., Freeman, C., Nelson, R.R., Silverberg, G., Soete, L. (Eds.), Technical Change and Economic Theory, London, Pinter, 590-607.

Atkinson, A.B. and Stiglitz, J.E. (1969), A New View of Technological Change, Economic Journal, 79, 573-8.

Audretsch, D.B., Keilbach, M.C. and Lehmann, E.E. (2006), Entrepreneurship and Economic Growth, Oxford, Oxford University Press.

Audretsch, D.B. and Mahmood, T. (1995), New Firm Survival: New Results Using a Hazard Function, Review of Economics and Statistics, 77, 97-103.

Audretsch, D.B., Santarelli, E. and Vivarelli, M. (1999a), Start Up Size and Industrial Dynamics: Some Evidence from Italian Manufacturing, International Journal of Industrial Organization, 17, 965-83.

Audretsch, D.B., Santarelli, E. and Vivarelli, M. (1999b), Does Start Up Size Influence the Likelihood of Survival?, in Audretsch, D. and Thurik, R. (eds.), Innovation, Industry Evolution and Employment, Cambridge, Cambridge University Press, 280-96.

Audretsch, D. and Vivarelli, M. (1996), Firm Size and R\&D Spillovers: Evidence from Italy, Small Business Economics, 8, 249-258.

Autor, D., L. Katz, and Krueger, A. (1998), Computing Inequality: Have Computers Changed the Labor Market? Quarterly Journal of Economics, 113, 1169-214.

Balassa, B. (1965), Trade Liberalization and Revealed Comparative Advantage, Manchester School of Economic and Social Studies, 33, 99-123.

Balassa, B. (1977), 'Revealed' Comparative Advantage Revisited: An Analysis of Relative Export Shares of the Industrial Countries, 1953-1971, Manchester School of Economic and Social Studies, 45, 327-44.

Baldwin, J.R. and Gorecki, P.K. (1987), Plant Creation Versus Plant Acquisition: The Entry Process in Canadian Manufacturing, International Journal of Industrial Organization, 5, 27-41. 
Baldwin, J.R. and Gorecki, P.K. (1991), Firm Entry and Exit in the Canadian Manufacturing Sector, Canadian Journal of Economics, 24, 300-23.

Barba Navaretti, G. and Solaga, I. (2002), Weightless Machines and Costless Knowledge - An Empirical Analysis of Trade and Technology Diffusion, CEPR Discussion Paper N. 3321, London, Centre for Economic Policy Research.

Barba Navaretti, G., I. Solaga, and Takacs, W. (1998), When Vintage Technology Makes Sense: Matching Imports to Skills, World Bank Working Paper 1923, Washington, DC, World Bank.

Bartelsman E., Haltiwanger, J. and Scarpetta, S. (2004), Microeconomic Evidence of Creative Destruction in Industrial and Developing Countries, World Bank Policy Research Working Paper 3464, Washington DC, World Bank.

Bartelsman, E., Scarpetta, S. and Schivardi, F. (2005), Comparative Analysis of Firm Demographics and Survival: Evidence from Micro-level Sources in OECD Countries, Industrial and Corporate Change, 14, 365-91.

Baumol, W.J (1990), Entrepreneurship: Productive, Unproductive and Destructive, Journal of Political Economy, 98, 893-921.

Baumol, W.J (2010), The Microtheory of Innovative Entrepreneurship, Princeton and Oxford, Princeton University Press.

Baumol, W.J., Litan, R.E. and Schramm, C.J. (2007), Good Capitalism, Bad Capitalism, New Haven, Yale University Press.

Beesley, M.E and Hamilton, R.T. (1984), Small Firms' Seedbed Role and the Concept of Turbulence, Journal of Industrial Economics, 33, 217-31.

Bell, M. and Pavitt, K. (1995), The Development of Technological Capabilities, in Haque, I.U. (Ed.), Trade, Technology and International Competitiveness, Washington, World Bank, 69-101.

Berman, E., Bound, J. and Griliches, Z. (1994), Changes in the Demand for Skilled Labor within U.S. Manufacturing Industries: Evidence from the Annual Survey of Manufacturing, Quarterly Journal of Economics, 109, 367-97.

Berman, E., and Machin, S. (2000), Skill-biased Technology Transfer Around the World, Oxford Review of Economic Policy, 16, 12-22.

Berman, E. and Machin, S. (2004), Globalization, Skill-biased Technological Change and Labor Demand, in E. Lee and Vivarelli, M. (Eds), Understanding Globalization, Employment and Poverty Reduction, New York, Palgrave Macmillan.

Bogliacino, F. and Vivarelli, M. (2012), The Job Creation Effect of R\&D Expenditures, Australian Economic Papers, 51, 96-113.

Bogliacino, F., Piva, M. and Vivarelli, M. (2012), R\&D and Employment: An Application of the LSDVC Estimator Using European Data, Economics Letters, 116, 56-59.

Breschi, S., Malerba, F. and Orsenigo, L. (2000), Technological Regimes and Schumpeterian 
Patterns of Innovation, Economic Journal, 110, 388-410.

Brouwer, E. and Kleinknecht, A. (1996), Firm Size, Small Business Presence and Sales in Innovative Products: A Micro-econometric Analysis, Small Business Economics, 8, 189-201.

Brouwer, E. and Kleinknecht, A. (1999), Keynes-plus? Effective Demand and Changes in Firmlevel R\&D: An Empirical Note, Cambridge Journal of Economics, 23, 385-91.

Bustos, P. (2005), The Impact of Trade on Technology and Skill Upgrading: Evidence from Argentina, Barcelona, CREI and Universitat Pompeu Fabra.

Caroli, E., and Van Reenen, J. (2001), Skill Biased Organizational Change? Evidence from a Panel of British and French Establishments, Quarterly Journal of Economics, 116, 1449-92.

Cassiman, B. and Veugelers, R. (2002), R\&D Cooperation and Spillovers, Some Empirical Evidence from Belgium, American Economic Review, 92, 1169-84.

Cefis, E. and Marsili, O. (2005), A Matter of Life and Death: Innovation and Firm Survival, Industrial and Corporate Change, 14, 1167-92.

Cefis, E. and Marsili, O. (2006), Survivor: The Role of Innovation in Firm's Survival, Research Policy, 35, 626-41.

Chung, W., and Yeaple, S. (2008), International Knowledge Sourcing: Evidence from US Firms Expanding Abroad, Strategic Management Journal 29, 1207-24.

Cimoli, M. and Dosi, G. (1995), Technological Paradigms, Patterns of Learning and Development: An Introductory Roadmap, Journal of Evolutionary Economics, 5, 243-68.

Cimoli, M., Dosi, G. and Stiglitz, J.E. (2009), Industrial Policy and Development: The Political Economy of Capabilities Accumulation, Oxford, Oxford University Press.

Cimoli, M. and Porcile, G. (2009), Sources of learning paths and technological capabilities: an introductory roadmap of development processes, Economics of Innovation and New Technology, 18, 675-94.

Cimoli, M., Porcile, G. and Rovira, S. (2010) Structural Change and the BOP-constraint: Why did Latin America Fail to Converge?, Cambridge Journal of Economics, 34, 389-411.

Cincera, M. and Veugelers, R. (2010), Europe’s Missing Yollies, ULB Institutional Repository No. 2013/106349, Bruxelles, Universite Libre de Bruxelles.

Coad, A. and Rao, R. (2008), Innovation and Firm Growth in High-tech Sectors: A Quantile Regression Approach, Research Policy, 37, 633-48.

Coe, D.T., and E. Helpman (1995), International R\&D Spillovers, European Economic Review, 39, 859-87.

Coe, D.T., E. Helpman and Homaister, A. (1997), North-South Spillovers, Economic Journal, 107, 134-149. 
Cohen, W.M. and Levinthal, D.A. (1989), Innovation and Learning: The Two Faces of R\&D, Economic Journal, 99, 569-96.

Cohen, W.M. and Levinthal, D.A. (1990), Absorptive Capacity: A New Perspective on Learning and Innovation, Administrative Science Quarterly, 35, 128-52.

Conte, A. and Vivarelli, M. (2011), Imported Skill Biased Technological Change in Developing Countries, Developing Economies, 49, 36-65.

Corsino, M. and Gabriele, R. (2011), Product Innovation and Firm Growth: Evidence from the Integrated Circuit Industry, Industrial and Corporate Change, 20, 29-56.

Cyert, R.M. and March, J.G. (1963), A Behavioural Theory of the Firm, Englewood Cliffs NJ, Prentice Hall.

Czarnitzki, D. (2006), Research and Development in Small and Medium-sized Enterprises: The Role of Financial Constraints and Public Funding, Scottish Journal of Political Economy, 53, 33557.

Czarnitzki, D. and Delanote, J., 2013. Young Innovative Companies: the New High-Growth Firms? Industrial and Corporate Change, 22, 1315-40.

Czarnitzki, D. and Hottenrott, H. (2011), R\&D Investment and Financing Constraints of Small and Medium-sized Firms, Small Business Economics, 36, 65-83.

Daude, C. and Fernandez-Arias, E. (2010), On the Role of Productivity and Factor Accumulation in Economic Development in Latin America and the Caribbean, Washington, Inter-American Development Bank.

David, P. (1985), Clio and the Economics of QWERTY, American Economic Review Proceedings, 75, 332-7.

Dejardin, M. (2011), Linking Net Entry to Regional Economic Growth, Small Business Economics, 36, 443-60.

Desai, S. (2009), Measuring Entrepreneurship in Developing Countries, Research paper / UNUWIDER, No. 2009.10, ISBN 978-92-9230-179-8.

Dosi, G. (1982), Technological Paradigms and Technological Trajectories, Research Policy, 11, 147-63.

Dosi, G. (1988), Sources, Procedures and Microeconomic Effects of Innovation, Journal of Economic Literature, 26, 1120-71.

Dosi, G., Marsili, O., Orsenigo, L. and Salvatore, R. (1995), Learning, Market Selection and the Evolution of Industrial Structures, Small Business Economics, 7, 411-36.

Dosi, G. and Nelson, R.R. (2013), The Evolution of Technologies: An Assessment of the State-ofthe-Art, Eurasian Business Review, 3, 3-46. 
Dosi, G, Nelson, R.R. and Winter, S. (2000) The Nature and Dynamics of Organizational Capabilities, Oxford, Oxford University Press.

Dunne, T., Roberts, M.J. and Samuelson, L. (1988), Patterns of Firm Entry and Exit in U.S. Manufacturing Industries, Rand Journal of Economics, 19, 495-515.

Dunne, T., Roberts, M.J. and Samuelson, L. (1989), The Growth and Failure of US Manufacturing Plants, Quarterly Journal of Economics, 104, 671-98.

EC-DG ENTR (2009), European Competitiveness Report 2008. Luxemburg, European Commission.

EIU (2004), Scattering the Seeds of Invention: The Globalisation of Research and Development, London, The Economist Intelligence Unit.

Eichengreen, B., Park, D. and Shin, K. (2012), When Fast-Growing Economies Slow Down: International Evidence and Implications for China, Asian Economic Papers, 11, 42-87.

Eichengreen, B., Park, D. and Shin, K. (2013), Growth Slowdowns Redux: New Evidence on the Middle-income Trap, Working Paper No. 18673, Cambridge Mass, National Bureau of Economic Research.

Epifani, P. (2003), Trade Lliberalization, Firm Performance, and Labor Market Outcomes in the Developing World: What can we Learn from Micro-level Data? Policy Research Working Paper Series, 3063, Washington, DC, World Bank.

Esteve-Pérez S., Sanchis A. and Sanchis J. A. (2004), The Determinants of Survival of Spanish Manufacturing Firms, Review of Industrial Organization, 25, 251-73.

Fagerberg, J. (1994), Technology and International Differences in Growth Rates, Journal of Economic Literature, 32, 1147-75.

Fagerberg, J. and Godinho, M. M. (2005), Innovation and Catching-up, in J. Fagerberg, D. Mowery and Nelson R.R., (Eds.), Handbook of Innovation, Oxford, Oxford University Press, 514-42.

Fajnzylber, P., and Fernandes, A. (2009), International Economic Activities and Skilled Labor Demand: Evidence from Brazil and China, Applied Economics, 41, 563-77.

Feenstra, R.C., and Hanson, G.H. (1997), Foreign Direct Investment and Relative Wages: Evidence from Mexico’s Maquiladoras, Journal of International Economics, 42, 371-93.

Felipe, J., Abdon, A. and Kumar, U. (2012), Tracking the Middle-income Trap: What is it, Who Is in It, and Why? Working Paper n. 715, Annandale-on-Hudson, Levy Economics Institute.

Florida, F. (1997), The Globalization of R\&D: Results of a Survey of Foreign-affiliated R\&D Laboratories in the USA, Research Policy, 26, 85-103.

Freel, M.S. (2000), Do Small Innovating Firms Outperform Non-innovators?, Small Business Economics, 14, 195-210. 
Freeman, C. (1987), Technology Policy and Economic Performance. Lessons from Japan, London, Pinter.

Freeman, C., Clark, J. and Soete, L. (1982), Unemployment and Technical Innovation, London, Pinter.

Freeman, C. and Perez, C. (1988), Structural Crises of Adjustment: Business Cycles and Investment Behaviour, in Dosi, G., Freeman, C., Nelson, R., Silverberg, G. and Soete, L. (Eds.), Technical change and Economic Theory, London, Pinter.

Freeman, C., and Soete, L. (Eds), (1987), Technical Change and Full Employment. Oxford, Basil Blackwell.

Freeman, C., and Soete, L. (1994), Work for All or Mass Unemployment? Computerised Technical Change into the Twenty-first Century, London and New York, Pinter.

Geroski, P.A. (1995), What do We know about Entry?, International Journal of Industrial Organization, 13, 421-40.

Geroski, P. and Walters, C.F. (1995), Innovative Activity over the Business Cycle, Economic Journal, 105, 916-28.

Gerschenkron, A. (1962), Economic Backwardness in Historical Perspective: A Book of Essays, Cambridge Mass., Belknap Press of Harvard University.

Gill, I., Kharas, H. with Bhattasali D. et al. (2007), An East Asian Renaissance: Ideas for Economic Growth, Washington DC, World Bank.

Goedhuys, M. and Sleuwaegen, L. (2010), High-growth Entrepreneurial Firms in Africa: A Quantile Regression Approach, Small Business Economics, 34, 31-51.

Görg, H., and Strobl, E. (2002), Relative Wages, Openness and Skill-Biased Technological Change, IZA Discussion Papers 596, Bonn, IZA.

Griliches, Z. (1969), Capital-skill Complementarity, Review of Economics and Statistics, 51, 465-68.

Grimalda, G. and Vivarelli, M. (2010), Is Inequality the Price to Pay for Higher Growth in MiddleIncome Countries?, Journal of Evolutionary Economics, 20, 265-306.

Grossman, G. M., and Helpman, E. (1991), Innovation and Growth in the Global Economy, Cambridge (Mass.), MIT Press.

Hall, P.H., and Heffernan, S.A. (1985), More on the Employment Effects of Innovation, Journal of Development Economics, 17, 151-62.

Hanson, G., and Harrison, A. (1999), Trade and Wage Inequality in Mexico, Industrial and Labor Relations Review, 52, 271-88.

Hanson, G., R. J. Mataloni, and Slaughter, M. J. (2005), Vertical Production Networks in Multinational Firms, Review of Economics and Statistics, 87, 664-78. 
Helpman, E., (2006). Trade, FDI and the Organization of Firms, Journal of EconomicLiterature, 44, 589-630.

Hidalgo, C., Klinger, B., Barabasi, A. L. and Hausmann, R. (2007), The Product Space Conditions the Development of Nations, Science, 317, 482-87.

Hidalgo, C. and Hausmann, R. (2009), "The building blocks of economic complexity, in Proceedings of the National Academy of Sciences, 106, No. 26, 10570-75.

Hobday, M. (1995), Innovation in East Asia: the Challenge to Japan, London, Elgar.

Hummels, D., Ishii, J. and Yi , K-M., (2001), The Nature and Growth of Vertical Specialization in World Trade, Journal of International Economics, 54, 75-96.

Iammarino, S. and McCann, P. (2013), Multinationals and Economic Geography: Location, Technology, and Innovation, Cheltenham, Elgar.

Ihrig, J. and Moe, K.S. (2004), Lurking in the Shadows: The Informal Sector and Government Policy, Journal of Development Economics, 73, 541-57.

Jankowska, A., Nagengast, A. and Perea, J.R. (2012), The Product Space and the Middle-Income Trap: Comparing Asian and Latin American Experiences, Working Paper No. 311, Paris, OECD Development Centre.

Johnson, P.S. (2005), Targeting Firm Births and Economic Regeneration in a Lagging Region, Small Business Economics, 24, 451-64.

Kaldor, N. (1967), Strategic Factors in Economic Development, New York State School of Industrial and Labor Relations, Cornell University.

Keller, W. (2004), International Technology Diffusion, Journal of Economic Literature, 42, 752-82.

Klapper, L., Amit, R. and Guillén, M.F, (2010), Entrepreneurship and Firm Formation across Countries, in Lerner, J and Schoar (eds) International Differences in Entrepreneurship, Chicago, University of Chicago Press.

Kleinknecht, A. and Verspagen, B. (1990), Demand and Innovation: Schmookler Re-examined, Research Policy, 19, 387-94.

Klevorick, A.K., Levin, R.C., Nelson, R.R. and Winter, S.G. (19959, On the Sources and Significance of Interindustry Differences in Technological Opportunities, Research Policy, 24, 185-205.

Koellinger, P. and Thurik, A.R. (2012), Entrepreneurship and the Business Cycle, Review of Economics and Statistics, 94, 1143-56.

Kuznets, S. (1955), Economic Growth and Income Inequality, American Economic Review, 45, 128. 
Kuznets, S. (1963), Quantitative Aspects of the Economic Growth of Nations, Economic Development and Cultural Change, 11, 1-80.

Lall, S. (1992), Technological Capabilities and Industrialization, World Development, 20, 165-86.

Lall, S. (2004), The Employment Impact of Globalization in Developing Countries, in Lee, E. and Vivarelli, M. (2004) (Eds), Understanding Globalization, Employment and Poverty Reduction, New York, Palgrave Macmillan, 73-101.

Laursen, K. (2014), Revealed Comparative Advantage and the Alternatives as Measures of International Specialization, Eurasian Business Review, forthcoming.

Lee, E., and Vivarelli, M. (2004) (Eds.), Understanding Globalization, Employment and Poverty Reduction, New York, Palgrave Macmillan.

Lee, E., and Vivarelli, M. (2006a) (Eds.), Globalization, Employment, and Income Distribution in Developing Countries, New York, Palgrave Macmillan.

Lee, E. and Vivarelli, M. (2006b), The Social Impact of Globalization in Developing Countries. International Labour Review, 145, 167-184.

Lewis, A. (1955), The Theory of Economic Growth, Homewood IL., Irwin.

Lucas, R.J. (2002), Lectures on Economic Growth, Massachusetts, Harvard University Press.

Lundvall, B.-Å. (1992), National Systems of Innovation, London, Pinter.

Machin, S. (1996), Changes in the Relative Demand for Skills in the UK Labor Market, in Booth, A. and Snower, D. (Eds.), Acquiring Skills: Market Failures, Their Symptoms and Policy Responses, Cambridge, Cambridge University Press, 129-46.

Machin, S. and Van Reenen, J. (1998), Technology and Changes in the Skill Structure: Evidence from Seven OECD Countries, Quarterly Journal of Economics, 113, 1215-44.

Malchow-Møller, N., Schjerning, B. and Sørensen, A. (2011), Entrepreneurship, Job Creation and Wage Growth, Small Business Economics, 36, 15-32.

Malerba, F (1992), Learning by Firms and Incremental Technical Change, Economic Journal, 102, 845-59.

Malerba, F. and Orsenigo, L. (1995), Schumpeterian Patterns of Innovation, Cambridge Journal of Economics, 19, 47-65.

Malerba, F. and Orsenigo, L. (1996), The Dynamics and Evolution of Industries, Industrial and Corporate Change, 5, 51-87.

Maloney, W. (2004), Informality Revisited, World Development, 32, 1159-78.

Mankiw, N.G., Romer, D. and Weil, D.N. (1992), A Contribution to the Empirics of Economic Growth, Quarterly Journal of Economics, 107, 407-37. 
Mansfield, E. (1988), Industrial R\&D in Japan and the United States: A Comparative Study. American Economic Review, 78, 223-28.

Marsili, O. (2001), The Anatomy and Evolution of Industries: Technological Change and Industrial Dynamics, Cheltenham, Elgar.

Marsili, O. and Verspagen, B. (2001), Technological Regimes and Innovation: Looking for Regularities in Dutch Manufacturing, Eindhoven, ECIS- Eindhoven University of Technology, May.

Marsili, O. and Verspagen, B. (2002), Technology and the Dynamics of Industrial Structures: An Empirical Mapping of Dutch Manufacturing, Industrial and Corporate Change, 11, 791-815.

Mata, J., Portugal, P. and Guimaraes, P. (1995), The Survival of New Plants: Start-up Conditions and Post-entry Evolution, International Journal of Industrial Organization, 13, 459-82.

Mayer, J. (2000), Globalization, Technology Transfer and Skill Accumulation in Developing Countries, UNCTAD Discussion Paper 150, Geneva, UNCTAD.

Mazzucato, M. (2011), The Entrepreneurial State, London, Demos.ó

Melitz, M. (2003), The Impact of Trade on Aggregate Industry Productivity and Intra-Industry Reallocations, Econometrica, 71, 1695-725.

Meschi, E., Taymaz, E. and Vivarelli, M. (2011), Trade, Technology and Skills: Evidence from Turkish Microdata, Labour Economics, 18, S60-S70.

Meschi, E. and Vivarelli, M. (2009), Trade and Income Inequality in Developing Countries, World Development, 37, 287-302.

Mohnen, P. and Hall, B.H. (2013), Innovation and Productivity: An Update, Eurasian Business Review, 3, 47-65.

Moncada-Paternò-Castello, P., Vivarelli, M. and Voigt, P. (2011), Drivers and Impacts in the Globalization of Corporate R\&D: An Introduction Based on the European Experience, Industrial and Corporate Change, 20, 585-603.

Montobbio, F. and Rampa, F. (2005), The Impact of Technology and Structural Change on Export Performance in Nine Developing Countries," World Development, 33, 527-47.

Montobbio, F. and Sterzi, V. (2013), The Globalization of Technology in Emerging Markets: A Gravity Model on the Determinants of International Patent Collaborations, World Development, 44, 281-99.

Mowery, D.C. (1983), Economic Theory and Government Technology Policy, Policy Sciences, 16, 27-43.

Mowery, D. and Rosenberg, N. (1979), The Influence of Market Demand Upon Innovation: a Critical Review of some Recent Empirical Studie, Research Policy, 8, 102-53. 
Naudé, W.A. (2009), Out With the Sleaze, in With the Ease: Insufficient for Entrepreneurial Development?, UNU-WIDER Research Paper no. 2009/01, United Nations University, Helsinki.

Naudé, W. (2010), Entrepreneurship, Developing Countries, and Development Economics: New Approaches and Insights, Small Business Economics, 34, 1-12.

Nelson, R.R. (1993), National Innovation Systems: A Comparative Analysis, Oxford, Oxford University Press.

Nelson, R.R. and Winter, S.G. (1982), An Evolutionary Theory of Economic Change, Cambridge (Mass.), Belknap Press of Harvard University Press.

Newman, C., Rand, J., Tarp, F. and Thi Tue Anh, N. (2013), Trade Liberalization and Learning-byexporting: Evidence from Vietnam, paper presented at the UNU-WIDER Conference on Learning to Compete: Industrial Development and Policy in Africa, Helsinki, 24-25 June.

Nübler, I. (2011), Industrial Policies and Capabilities for Catching up: Frameworks and Paradigms, Employment Working Paper n. 77, Geneva, International Labour Office.

Nübler, I. (2013), Education Structures and Industrial Development: Lessons for Education Policies in African Countries, paper presented at the UNU WIDER Conference on Learning to Compete: Industrial Development and Policy in Africa, Helsinki, 24-25 June.

Nübler, I. (2014), Capabilities for Productive Transformation: Learning to Catch Up, in SalazarXirinachs, J.M., Nübler,I. and Kozul-Wright, R. (Eds.) Getting Industrial Policies Right for Growth, Jobs and Learning, Geneva, ILO and UNCTAD, forthcoming.

Pasinetti, L. (1981), Structural Change and Economic Growth, Cambridge, Cambridge University Press.

Pavitt K. (1984), Sectoral Patterns of Technical Change: Towards a Taxonomy and a Theory, Research Policy, 13, 343-73.

Perez, C. (1983), Structural Change and Assimilation of New Technologies in the Economic and Social Systems”, Futures, 15, 357-75.

Perez-Sebastian, F. (2007), Public Support to Innovation and Imitation in a Non-Scale Growth Model, Journal of Economic Dynamics and Control, 31, 3791-821.

Perkins, R., and Neumayer, E. (2005), International Technological Diffusion, Latecomer Advantage and Economic Globalization: A Multi-technology Analysis, Annals of the American Association of Geographers, 95, 789-808.

Petit, P. (1995), Employment and Technological Change, in P. Stoneman (Ed), Handbook of the Economics of Innovation and Technological Change, Amsterdam ,North Holland.

Pianta, M. (2005), Innovation and Employment, in J. Fagerberg, D. Mowery and Nelson R.R., (Eds.), Handbook of Innovation, Oxford, Oxford University Press, 568-98.

Piga, C.A. and Vivarelli, M. (2003), Sample Selection in Estimating the Determinants of Cooperative R\&D, Applied Economics Letters, 10, 243-6. 
Piga, C.A. and Vivarelli, M. (2004), Internal and External R\&D: A Sample Selection Approach, Oxford Bulletin of Economics and Statistics, 66, 457-82.

Piva, M. (2003), The Impact of Technology Transfer on Employment and Income Distribution in Developing Countries: A Survey of Theoretical Models and Empirical Studies, International Policy Group Working Paper 15, Geneva, International Labor Office.

Piva, M., Santarelli, E. and Vivarelli, M. (2005), The Skill Bias Effect of Technological and Organisational Change: Evidence and Policy Implications, Research Policy, 34, 141-57.

Piva, M. and Vivarelli, M. (2004), Technological Change and Employment: Some Micro Evidence from Italy, Applied Economics Letters, 11, 373-376.

Piva, M. and Vivarelli, M. (2007), Is Demand-pulled Innovation Equally Important in Different Groups of Firms?, Cambridge Journal of Economics, 31, 691-710.

Piva, M. and Vivarelli, M. (2009a), Demand-pulled Innovation under Liquidity Constraints, Applied Economics Letters, 16, 289-293.

Piva, M. and Vivarelli, M. (2009b), The Role of Skills as a Major Driver of Corporate R\&D, International Journal of Manpower, 30, 835-852.

Raspe, O. and Van Oort, F. G. (2008), Firm Growth and Localized Knowledge Externalities, Journal of Regional Analysis and Policy, 38, 100-16.

Reid, G.C. (1991), Staying in Business, International Journal of Industrial Organization, 9, 545-56.

Reynolds, P.D. (1997), Who Starts New Firms? - Preliminary Explorations of Firms-in-Gestation, Small Business Economics, 9, 449-62.

Robbins, D. (1996), HOS Hits Facts: Facts Win; Evidence on Trade and Wages in the Developing World, OECD Technical Paper 119, Paris, OECD.

Robbins, D. (2003), The Impact of Trade Liberalization upon Inequality in Developing Countries A review of Theory and Evidence. ILO Working Paper, n.13, Geneva, International Labour Organization.

Robbins, D. and Gindling, T.H. (1999), Trade Liberalization and the Relative Wages for MoreSkilled Workers in Costa Rica. Review of Development Economics, 3, 140-154.

Romer, P.M. (1994), The Origins of Endogenous Growth, Journal of Economic Perspectives, 8, 322.

Rosenberg, N. (1982), Inside the Black Box: Technology and Economics, Cambridge, Cambridge University Press.

Rosenberg, N. (1990), Why do Firms Do Basic Research With their Own Money? Research Policy, 19, 165-74.

Rosenberg, N. (1994), Exploring the Black Box: Technology, Economics, and History, Cambridge, Cambridge University Press. 
Rostow, W. W. (1959), The Stages of Economic Growth, Economic History Review, 12, 1-16.

Ruttan, V.W. (1997), Induced Innovation, Evolutionary Theory and Path Dependence: Sources of Technical Change, Economic Journal, 107, 1520-29.

Santarelli, E. and Tran, H. T. (2011), Growth of Incumbent Firms and Entrepreneurship in Vietnam, Working Papers DSE n. 785, Bologna, Dipartimento Scienze Economiche - Universita' di Bologna.

Santarelli, E. and Vivarelli, M. (2002), Is Subsidizing Entry an Optimal Policy?, Industrial and Corporate Change, 11, 39-52.

Santarelli, E. and Vivarelli, M. (2007), Entrepreneurship and the Process of Firms' Entry, Survival and Growth, Industrial and Corporate Change, 16, 455-88.

Scherer, F.M. (1982), Demand-pull and Technological Invention: Schmookler Revisited, Journal of Industrial Economics, 30, 225-37.

Schmookler, J. (1962) Economic Sources of Inventive Activity, Journal of Economic History, 22, $1-10$.

Schmookler, J. (1966), Invention and Economic Growth, Cambridge (Mass.), Harvard University Press.

Schneider, C. and Veugelers, R. (2010), On Young óhly Innovative Companies: Why They Matter and How (not) to Policy Support them, Industrial and Corporate Change, 19, 969-1007.

Schumpeter, J.A. (1934), The Theory of Economic Development, Cambridge (Mass.), Harvard University Press.

Schumpeter, J.A. (1939), Business Cycles: A Theoretical, Historical and Statistical Analysis of the Capitalist Process, New York, McGraw-Hill.

Schumpeter, J.A. (1942), Capitalism, Socialism and Democracy, New York, Harper.

Simon, H. (1955), A Behavioral Model of Rational Choice, Quarterly Journal of Economics, 69, 99-118.

Sonobe, T., Akoten, J.E. and Otsuka, K. (2011), The Growth Process of Informal Enterprises in Sub-Saharan Africa: A Case Study of a Metalworking Cluster in Nairobi, Small Business Economics,36, 323-35.

Spence, M. (2011), The Next Convergence. The Future of Economic Growth in a Multispeed World, New York, Farrar Strauss and Giroux.

Sutton, J. (2012), Competing in Capabilities: The Globalization Process, Oxford, Oxford University Press.

Sylos Labini, P. (1969), Oligopoly and Technical Progress, Cambridge (Mass.), Harvard University Press. 
Taylor, L. (2004), External Liberalization in Asia, Post-Socialist Europe and Brazil, in E. Lee and Vivarelli, M. (Eds), Understanding Globalization, Employment and Poverty Reduction, New York, Palgrave Macmillan.

Teece, D.J., Pisano, G. and Shuen, A. (1997), Dynamic Capabilities and Strategic Management, Strategic Management Journal, 18, 509-33.

Thursby, J. and Thursby, M., (2006), Here or There? A Survey on the Factors in Multinational $R \& D$ Location, Washington DC, National Academies Press.

UNCTAD (2005), Transnational Corporations and the Internationalization of R\&D, World Investment Report, New York and Geneva, United Nations.

Van Praag, M.C. and Versloot, P.H. (2007), What Is the Value of Entrepreneurship?, A Review of Recent Research, Small Business Economics,29, 351-82.

Verhoogen, E.A. (20089, Trade, Quality Upgrading, and Wage Inequality in the Mexican Manufacturing Sector, Quarterly Journal of Economics, 123, 489-530.

Veugelers, R. (1997), Internal R\&D Expenditures and External Technology Sourcing. Research Policy, 26, 303-15.

Vivarelli, M. (1995), The Economics of Technology and Employment: Theory and Empirical Evidence, Cheltenham, Elgar.

Vivarelli, M. (2004), Globalization, Skills and Within-Country Income Inequality in Developing Countries, in E. Lee and Vivarelli, M. (Eds.), Understanding Globalization, Employment and Poverty Reduction, New York, Palgrave Macmillan.

Vivarelli, M. (2012), Drivers of Entrepreneurship and Post-entry Performance: Microeconomic Evidence from Advanced and Developing Countries, Policy Research Working Paper Series $n$. 6245, Washington DC, World Bank.

Vivarelli, M. (2013a), Technology, Employment and Skills: An Interpretative Framework, Eurasian Business Review, 3, 66-89.

Vivarelli, M. (2013b), Is Entrepreneurship Necessarily Good? Microeconomic Evidence from Developed and Developing Countries, Industrial and Corporate Change, 22, 1453-1495.

Vivarelli, M., Evangelista, R. and Pianta, M. (1996), Innovation and Employment: Evidence from Italian Manufacturing, Research Policy, 25, 1013-1026.

Vivarelli, M., and Pianta, M. (2000), The Employment Impact of Innovation: Evidence and Policy, London, Routledge.

Von Tunzelmann, N. (2009), Regional Capabilities and Industrial Regeneration, in Farshchi, M., Janne, O. and McCann, P. (Eds), Technological Change and Mature Industrial Regions: Firms, Knowledge and Policy, Cheltenham, Elgar, 11-28.

Von Tunzelmann, N. and Wang, Q. (2003), An Evolutionary View of Dynamic Capabilities, Economie Appliquée, 6, 33-64. 
Von Tunzelmann, N. and Wang, Q. (2007), Capabilities and Production Theory, Structural Change and Economic Dynamics, 18, 192-211.

Welch, F. (1970), Education in Production, Journal of Political Economy, 78, 35-59.

Wennekers, S. and. Thurik, A.R. (1999), Linking Entrepreneurship and Economic Growth, Small Business Economics, 13, 27-55.

Winter, S.G. (1984), Schumpeterian Competition in Alternative Technological Regimes, Journal of Economic Behavior and Organization, 5, 287-320.

Wood, A. (1994), North-south Trade, Employment, and Inequality: Changing Fortunes in a Skilldriven World, Oxford, Clarendon Press.

Wood, A., and Ridao-Cano, C. (1999), Skill, Trade and International Inequality, Oxford Economic Papers, 51, 89-119.

World Bank (2012), China 2030: Building a Modern, Harmonious and Creative Society, Washington DC, World Bank.

Yamada, G. (1996), Urban Informal Employment and Self-Employment in Developing Countries: Theory and Evidence, Economic Development and Cultural Change, 44, 289-314.

Yeaple, S.R. (2005), A Simple Model of Firm Heterogeneity, International Trade and Wages, Journal of International Economics, 65, 1-20.

Zollo, M. and Winter, S. G. (2002), Deliberate Learning and the Evolution of Dynamic Capabilities, Organization Science, 13, 339-51. 